\title{
Feedback interactions between trace metal nutrients and phytoplankton in the ocean
}

\author{
William G. Sunda* \\ National Ocean Service, National Oceanic and Atmospheric Administration, Beaufort, NC, USA
}

Edited by:

Martha Gledhill, University of

Southampton, UK

\section{Reviewed by:}

Christel Hassler, University of Technology Sydney, Australia Kenneth Bruland, University of California at Santa Cruz, USA

\section{*Correspondence:}

William G. Sunda, National Ocean Service, National Oceanic and Atmospheric Administration, 101 Pivers Island Road, Beaufort, NC 28512, USA.

e-mail: bill.sunda@noaa.gov
In addition to control by major nutrient elements (nitrogen, phosphorus, and silicon) the productivity and species composition of marine phytoplankton communities are also regulated by a number of trace metal nutrients (iron, zinc, cobalt, manganese, copper, and cadmium). Of these, iron is most limiting to phytoplankton growth and has the greatest effect on algal species diversity. It also plays an important role in limiting di-nitrogen $\left(\mathrm{N}_{2}\right)$ fixation rates, and thus is important in controlling ocean inventories of fixed nitrogen. Because of these effects, iron is thought to play a key role in regulating biological cycles of carbon and nitrogen in the ocean, including the biological transfer of carbon to the deep sea, the so-called biological $\mathrm{CO}_{2}$ pump, which helps regulate atmospheric $\mathrm{CO}_{2}$ and $\mathrm{CO}_{2}$-linked global warming. Other trace metal nutrients (zinc, cobalt, copper, and manganese) have lesser effects on productivity; but may exert an important influence on the species composition of algal communities because of large differences in metal requirements among species. The interactions between trace metals and ocean plankton are reciprocal: not only do the metals control the plankton, but the plankton regulate the distributions, chemical speciation, and cycling of these metals through cellular uptake and recycling processes, downward flux of biogenic particles, biological release of organic chelators, and mediation of redox reactions. This two way interaction has influenced not only the biology and chemistry of the modern ocean, but has had a profound influence on biogeochemistry of the ocean and earth system as a whole, and on the evolution of marine and terrestrial biology over geologic history.

Keywords: Phytoplankton, trace metal nutrients, iron, zinc, cobalt, manganese, cadmium, trace metal chemistry

\section{INTRODUCTION}

Life in the ocean is dependent on fixation of carbon (C) and nitrogen $(\mathrm{N})$ by planktonic microalgae, ranging in diameter from $<1$ to $>100 \mu \mathrm{m}$. These "phytoplankton" consist of eukaryotic algae, which photosynthetically fix carbon dioxide $\left(\mathrm{CO}_{2}\right)$ into organic matter, and cyanobacteria that fix $\mathrm{CO}_{2}$ and also fix di-nitrogen $\left(\mathrm{N}_{2}\right)$ to form ammonium. They make up less than $1 \%$ of the plant biomass on earth, but account for almost $50 \%$ of global primary production (Field et al., 1998) and are a major source of trace gases such as dimethylsulfide that influence climate (Charlson et al., 1987; Andreae and Crutzen, 1997). Up until the ground breaking experiments of John Martin (Martin and Fitzwater, 1988; Martin et al., 1991), the growth of marine phytoplankton was thought to be primarily limited by the availability of the major nutrient nitrogen and to a lesser extent phosphorus. However, numerous iron-addition experiments in bottles and in mesoscale patches of surface seawater in the ensuing decades have demonstrated that the trace metal nutrient iron limits the growth of phytoplankton and regulates their species composition in $30-40 \%$ of the world ocean, especially in high nitrate-low chlorophyll (HNLC) regions: the Southern Ocean, the equatorial and subarctic Pacific, and some coastal upwelling systems (Hutchins et al., 2002; Moore et al., 2002, 2004; Coale et al., 2004; Boyd et al., 2007). In addition, there is substantial evidence that iron limits the fixation of $\mathrm{N}_{2}$ by cyanobacteria in the ocean, and thus, controls oceanic inventories of biologically available fixed nitrogen (Rueter, 1983; Falkowski, 1997; Wu et al., 2000; Sohm et al., 2011). Several other trace metal nutrients (zinc, cobalt, manganese, and copper) have also been shown to stimulate phytoplankton growth in bottle incubation experiments with natural ocean water, but their effects are usually less substantial than those for iron (Coale, 1991; Crawford et al., 2003; Franck et al., 2003; Saito et al., 2005). However, these metals may play important roles in regulating the species composition of phytoplankton communities because of large differences in cellular trace metal concentrations and growth requirements among species (Brand et al., 1983; Sunda and Huntsman, 1995a,b; Crawford et al., 2003; Ho et al., 2003).

In this review, I will discuss interactions between trace metal nutrients [iron $(\mathrm{Fe})$, zinc $(\mathrm{Zn})$, cobalt $(\mathrm{Co})$, manganese $(\mathrm{Mn})$, copper $(\mathrm{Cu})$, nickel $(\mathrm{Ni})$, cadmium $(\mathrm{Cd})$, and molybdenum $(\mathrm{Mo})]$ and phytoplankton in the ocean. These interactions involve not only the effect of the metals on the growth and species composition of phytoplankton communities, but also the profound effect of marine plankton on the distribution, speciation chemistry, and biological availability of these nutrient metals (Figure 1). There are many aspects to consider in these interactions, including (1) the distribution of metal nutrients in the ocean on various temporal and spatial scales; (2) the sources, sinks, and cycling of metals; (3) 


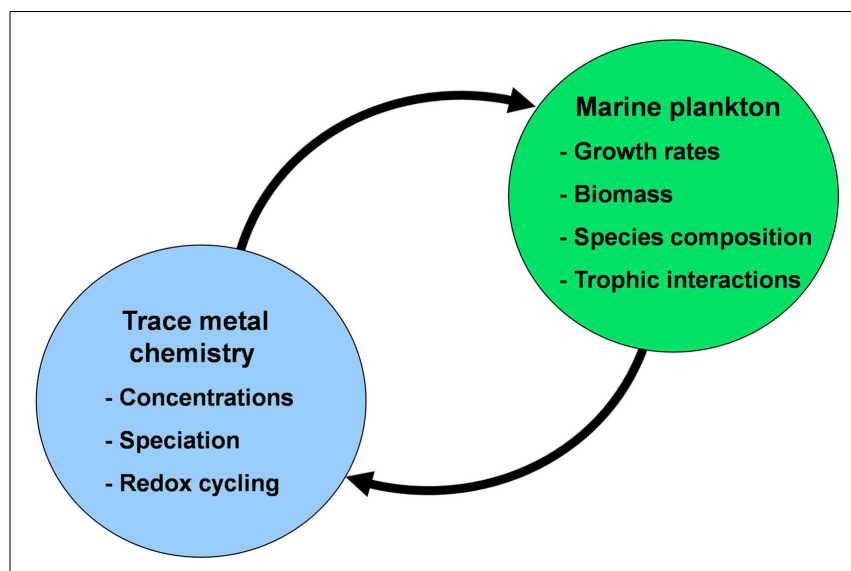

FIGURE 1 | Conceptual diagram of the mutual interactions between trace metal nutrients ( $\mathrm{Fe}, \mathrm{Mn}, \mathrm{Zn}, \mathrm{Co}, \mathrm{Cu}, \mathrm{Mo}$, and $\mathrm{Cd}$ ) and phytoplankton in the sea. In these interactions the chemistry of trace metal nutrients (their concentrations, chemical speciation, and redox cycling) regulate the productivity, species composition, and trophic interactions of marine phytoplankton communities. These communities in turn regulate the chemistry and cycling of the trace metals through cellular uptake and assimilation, vertical transport of biogenic particles (intact cells and fecal pellets), mediation of metal regeneration processes (by grazers, bacteria, and viruses), production of organic chelators, and biological mediation of metal redox cycling.

metal speciation and redox cycling, (4) the influence of these metals on phytoplankton metabolism and growth at different levels of biological organization (molecular, cellular, population, community, ecosystem, ocean/earth system), and (5) the influence of phytoplankton and the planktonic community as a whole on the chemistry and cycling of metal nutrients in the ocean.

\section{METAL DISTRIBUTIONS IN THE OCEAN}

The distribution patterns of trace metal nutrients in the ocean have a profound influence on phytoplankton communities. Concentrations of filterable Fe and $\mathrm{Zn}$ (that which passes through a 0.2 or $0.4 \mu \mathrm{m}$-pore filter) are often extremely low $(0.02-0.1 \mathrm{nM})$ in surface open ocean waters (Bruland, 1980; Martin et al., 1989; Johnson et al., 1997). Filterable concentrations of Cd, a nutrient analog for $\mathrm{Zn}$, can reach values as low as $0.002-0.004 \mathrm{nM}$ in surface waters of the North Pacific and Atlantic Oceans (Bruland, 1980; Bruland and Franks, 1983; Table 1). Filterable levels of these and other trace metal nutrients can increase by orders of magnitude in surface transects from the open ocean to coastal and estuarine waters owing to metal inputs from continental sources: rivers, ground water, aeolian dust, and coastal sediments (Bruland and Franks, 1983; Sunda, 1988/89). Filterable Fe can reach micromolar levels in estuaries and 10-20 $\mu \mathrm{M}$ in high humic rivers, 1000 to 10,000 -fold higher than concentrations in surface ocean waters. Filterable iron in rivers occurs largely as colloidal particles (0.02-0.4 $\mu \mathrm{m}$ diameter), which are rapidly lost from estuarine and coastal waters via salt-induced coagulation and particulate settling (Boyle et al., 1977). Because of this efficient removal, much of the iron in rivers is deposited in estuarine and coastal sediments, and little directly reaches the open sea. However, reducing conditions in organic-rich shelf and margin sediments can re-mobilize some of the river-derived particulate Fe via reduction to soluble $\mathrm{Fe}(\mathrm{II})$, and thereby provide an important Fe source to the ocean (Moore and Braucher, 2008). Another equally if not more important source of iron to the ocean is aeolian deposition of iron-containing mineral dust transported by the wind from arid regions (Duce and Tindale, 1991; Jickells et al., 2005). These aeolian inputs change seasonally with variations in rainfall and prevailing winds and are highest in waters downwind of deserts (Measures and Vink, 1999; Jickells and Spokes, 2001). Regions far removed from aeolian and sedimentary continental sources, such as the South Pacific and Southern Ocean receive low external iron inputs and are among the most ironlimited areas of the oceans (Martin et al., 1990; Behrenfeld and Kolber, 1999; Coale et al., 2004). Other external sources such as glaciers/iceberg melt, seasonal sea ice melting, island wakes, volcanism, and hydrothermal activity can provide important local inputs of iron and other metals (Boyd and Ellwood, 2010).

Because of the much lower trace metal concentrations in the open ocean relative to those in coastal waters, oceanic algal species have evolved the ability to grow at much lower external and intracellular concentrations of $\mathrm{Fe}, \mathrm{Zn}$, and $\mathrm{Mn}$ (Brand et al., 1983; Brand, 1991; Sunda and Huntsman, 1986, 1992, 1995a,b). In doing so they have been forced to rearrange their metabolic architecture (e.g., by decreasing the abundance of iron-rich protein complexes [photosystem I and the cytochrome $b_{6} / f$ complex] in photosynthesis; Strzepek and Harrison, 2004), by switching from ironcontaining enzymes to less carbon-efficient metal free enzymes (the replacement of ferredoxin by flavodoxin in photosynthetic electron transport (La Roche et al., 1996) and $\mathrm{N}_{2}$-fixation (Saito et al., 2011), or by switching from scarce metals to more-abundant ones in some critical metalloenzymes [e.g., the replacement of cytochrome $c_{6}$ which contains iron with the copper protein plastocyanin in photosynthetic electron transport (Peers and Price, 2006)].

Residence times of trace metal nutrients in the ocean vary over a wide range - from 20 to 40 years for Mn (Landing and Bruland, 1987; Bruland et al., 1994) to 800,000 years for Mo (Emerson and Huested, 1991; Morford and Emerson, 1999). Concentrations of $\mathrm{Zn}, \mathrm{Cd}, \mathrm{Ni}$, and $\mathrm{Cu}$, which have intermediate to long residence times (3000-100,000 years; Bruland and Lohan, 2003) relative to the average ventilation time of ocean water $(\sim 1000$ years for deep ocean water), increase with depth, similar to increases observed for major nutrients (nitrate, phosphate, and silicic acid; Figures 2 and 3). In the northeast Pacific, filterable concentrations of $\mathrm{Zn}$ and $\mathrm{Cd}$ increase by 80 -fold and 400 -fold, respectively, between the surface and $1000 \mathrm{~m}$ (Bruland, 1980). The similarity between vertical profiles of trace metal nutrients and those of major nutrients suggest that both sets of nutrients undergo similar biological uptake and regeneration processes in which each is taken up by phytoplankton in sunlit surface waters and are thereby efficiently removed from solution. Much of these assimilated metals and major nutrients are recycled within the euphotic zone by the coupled processes of zooplankton grazing and excretion, viral lysis of cells, and bacterial degradation of organic materials (Hutchins et al., 1993; Hutchins and Bruland, 1994; Poorvin et al., 2004; Strzepek et al., 2005; Boyd and Ellwood, 2010). However, a portion of the assimilated metals and major nutrients is continuously lost from the euphotic zone by vertical settling of biogenic particulate matter, including intact 


\begin{tabular}{|c|c|c|c|c|c|c|c|c|c|}
\hline \multirow[t]{2}{*}{ Metal } & \multirow{2}{*}{$\begin{array}{l}\text { Depth (m) } \\
\text { (Obs.) }\end{array}$} & \multirow[t]{2}{*}{ Total M (nM) } & \multirow{2}{*}{$\begin{array}{l}\text { L1 (nM) } \\
\text { L2 (nM) }\end{array}$} & \multirow{2}{*}{$\begin{array}{l}\log \mathrm{K}_{\mathrm{L} 1, \mathrm{M}^{\prime}} \\
\log \mathrm{K}_{\mathrm{L} 2, \mathrm{M}^{\prime}}\end{array}$} & \multirow[t]{2}{*}{$-\log \left[M^{\prime}\right]$} & \multicolumn{3}{|c|}{ Percent total metal } & \multirow[t]{2}{*}{ Reference } \\
\hline & & & & & & $\left(\mathbf{M}^{\prime}\right)$ & $\mathrm{ML}_{1}$ & $\mathrm{ML}_{2}$ & \\
\hline \multirow[t]{2}{*}{$\mathrm{Fe}$} & $\begin{array}{l}20-300 \\
(6)\end{array}$ & $0.22 \pm 0.07$ & $\begin{array}{l}0.48 \pm 0.07 \\
1.47 \pm 0.07\end{array}$ & $\begin{array}{l}13.04 \pm 0.16 \\
11.49 \pm 0.10\end{array}$ & $13.2 \pm 0.2$ & $0.03 \pm 0.01$ & $86.5 \pm 2.7$ & $13.5 \pm 2.7$ & Rue and Bruland (1995) \\
\hline & $\begin{array}{l}500-2000 \\
\text { (3) }\end{array}$ & $0.72 \pm 0.05$ & $\begin{array}{l}\text { n.d } \\
2.57 \pm 0.21\end{array}$ & $\begin{array}{l}\text { n.d. } \\
11.58 \pm 0.16\end{array}$ & $12.0 \pm 0.2$ & $0.15 \pm 0.06$ & n.d & $99.8 \pm 0.1$ & Rue and Bruland (1995) \\
\hline $\mathrm{Cu}$ & $\begin{array}{l}25-120 * \\
(18)\end{array}$ & $0.53 \pm 0.07$ & $\begin{array}{c}1.77 \pm 0.56 \\
5.7 \pm 2.8\end{array}$ & $\begin{array}{r}11.58 \pm 0.30 \\
8.72 \pm 0.46\end{array}$ & $11.9 \pm 0.2$ & $0.31 \pm 0.24$ & $98.8 \pm 0.9$ & $0.9 \pm 0.7$ & Coale and Bruland (1990) \\
\hline $\mathrm{Zn}$ & $\begin{array}{l}22-200 \\
\text { (9) }\end{array}$ & $0.23 \pm 0.07$ & $1.15 \pm 0.19$ & $10.66 \pm 0.13$ & $11.3 \pm 0.3$ & $2.6 \pm 1.0$ & $97.4 \pm 1.0$ & n.d. & Bruland (1989) \\
\hline $\mathrm{Cd}$ & $\begin{array}{l}600 \\
(2)\end{array}$ & 0.78 & n.d. & n.d. & $9.0 \pm 0.0$ & 100 & n.d. & n.d. & Bruland (1992) \\
\hline
\end{tabular}

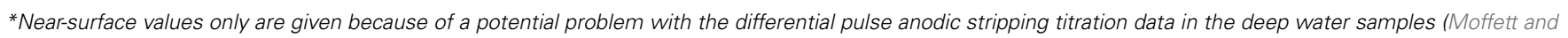
Dupont, 2007).

algal cells, zooplankton fecal pellets, and organic detritus. The macro- and micro-nutrients contained in these settling biogenic particles are then returned to solution in non-lit deeper waters by bacterial degradation processes, with the rate of this regeneration decreasing exponentially with water depth. Over time the uptake, settling, and regeneration processes deplete trace metal and major nutrients in sunlit surface waters to low levels and increase concentrations at depth at elemental ratios equal to average values in phytoplankton. This set of processes also transfers $\mathrm{CO}_{2}$ to the deep sea and is important in regulating atmospheric $\mathrm{CO}_{2}$ concentrations (Sigman and Boyle, 2000). The cycle is completed when the nutrient and $\mathrm{CO}_{2}$ reservoirs in deeper waters are returned to the surface via vertical mixing and advection (upwelling) processes.

Based on the above dynamics, the plots of trace metal nutrients with longer residence times $(\mathrm{Cu}, \mathrm{Zn}, \mathrm{Ni}$, and $\mathrm{Cd})$ vs those of major nutrients (e.g., phosphate) should have slopes equal the average ratios of trace metals to major nutrients in marine plankton. Such behavior was previously demonstrated for depth dependent plots of nitrate vs phosphate concentrations in which the slope of these relationships $\left(16 \mathrm{~mol} \mathrm{~mol}{ }^{-1}\right)$ equaled the average N:P measured in ocean plankton (Redfield et al., 1963). Similar behavior has been observed for plots of $\mathrm{Zn}, \mathrm{Cd}, \mathrm{Ni}$, and $\mathrm{Cu}$ vs phosphate, but with several caveats (Martin et al., 1976; Sunda and Huntsman, 1992, 1995c, 2000; Croot et al., 2011; Figure 4). In depth profiles for the northeastern Pacific (Figure 2), the concentrations of three of the metals $(\mathrm{Ni}, \mathrm{Cu}, \mathrm{Cd})$ within the nutricline are linearly related to those of phosphate, and for $\mathrm{Cu}$ and $\mathrm{Cd}$, the metal:P slopes (or equivalent metal:C ratios) agree well with values measured in net plankton samples or in algae cultured at the concentration of unchelated metal $\left[\mathrm{M}^{\prime}\right]$ (or other controlling metals in the case of Cd) observed in the sunlit surface layer (Figures 4B,C; Table 2). However, unlike $\mathrm{N}$ vs $\mathrm{P}$ plots, these relationships have positive $y$-intercepts for $\mathrm{Cu}$ and $\mathrm{Ni}$, indicating that these metals are not completely "used up" biologically in N- and P-depleted surface waters. By contrast, the $\mathrm{Zn}$ :P relationship exhibits increasing slopes with increasing $\mathrm{Zn}$ concentrations and a negative $y$-intercept for a linear regression of $\mathrm{Zn}$ vs $\mathrm{P}$ (Figure 4A; Table 2). Here the $\mathrm{Zn}: \mathrm{P}$ slope (and associated $\mathrm{Zn}: \mathrm{C}$ molar ratio) in the productive surface layer $(0-185 \mathrm{~m})$ agrees with $\mathrm{Zn}: \mathrm{P}$ and $\mathrm{Zn}: \mathrm{C}$ values for marine algae grown at the measured $\left[\mathrm{Zn}^{\prime}\right]$ range within the surface layer (Tables 1 and 2; Figure 5) and the $\mathrm{Zn}: \mathrm{C}$ ratio $(3.7 \mu \mathrm{mol}$ $\mathrm{mol}^{-1}$ ) in phytoplankton growing in near-surface seawater in the northeast Pacific (Lohan et al., 2005). However at greater depths $(185-800 \mathrm{~m})$, the $\mathrm{Zn}: \mathrm{P}$ slope and associated $\mathrm{Zn}: \mathrm{C}$ ratio $(22 \mu \mathrm{mol}$ $\left.\mathrm{mol}^{-1}\right)$ is similar to average values for phytoplankton growing at the much higher $\left[\mathrm{Zn}^{\prime}\right]$ range observed at depth (Sunda and Huntsman, 1992; Table 2; Figure 5).

The non-linearity of the $\mathrm{Zn}$ vs $\mathrm{P}$ plots likely reflects the very large variation in $\left[\mathrm{Zn}^{\prime}\right]$ in ocean waters and the associated variation in $\mathrm{Zn}: \mathrm{P}$ and $\mathrm{Zn}: \mathrm{C}$ ratios in phytoplankton growing in these waters (Sunda and Huntsman, 1992). Although waters with high $\left[\mathrm{Zn}^{\prime}\right]$ are usually found below the photic zone, and thus, cannot influence the removal of metals by algal growth and uptake, thermohaline and wind-driven upwelling can bring these high-nutrient, high-zinc waters to the surface, especially in polar regions. As a consequence of these processes, filterable $\mathrm{Zn}$ in surface waters of the Atlantic sector of the Southern Ocean increased from $0.5 \mathrm{nM}$ at a latitude of $46^{\circ} \mathrm{S}$ to $4.5 \mathrm{nM}$ at $66^{\circ} \mathrm{S}$ along with increases in phosphate and nitrate (Croot et al., 2011). The [ $\left.\mathrm{Zn}^{\prime}\right]$ in surface waters increased to as high $1.8 \mathrm{nM}$, as the zinc concentration exceeded that of strong $\mathrm{Zn}$ binding ligands (Baars and Croot, 2011), a value $\sim 400$-fold higher than mean surface $\left[\mathrm{Zn}^{\prime}\right]$ in the North Pacific (Table 1). Subsequently, the lateral changes in nutrient and metal concentrations in these near-surface waters caused by algal uptake, 


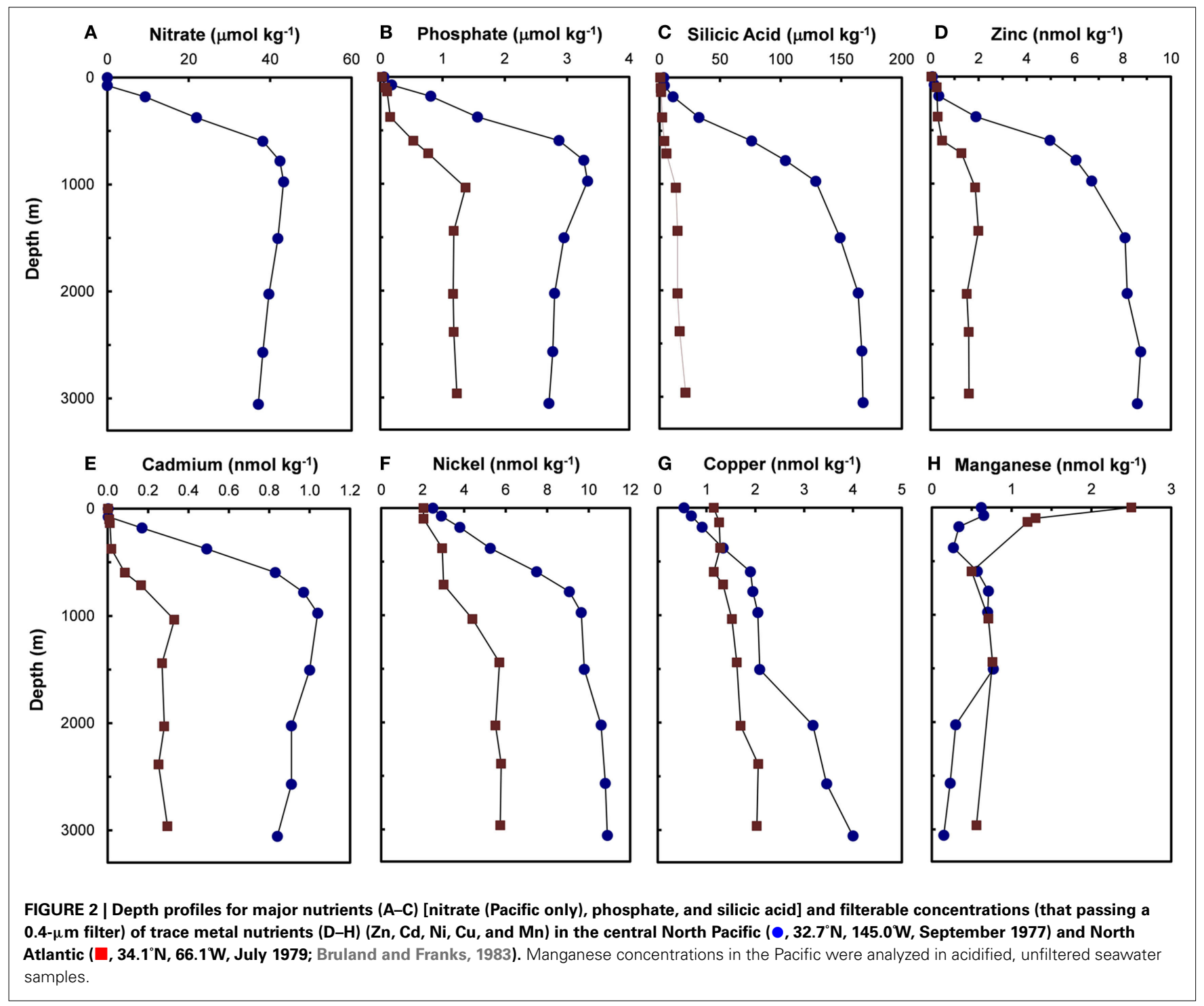

biogenic particulate settling, and net regeneration in deeper waters are transposed to deeper depths and more northern latitudes with downwelling and lateral advection, which is most intense during winter (Redfield et al., 1963). In this way near-surface processes of algal uptake, settling, and shallow water regeneration can influence the composition and vertical structure of major and trace metal nutrients in deep ocean waters worldwide. Indeed, at depths at and just above the phosphate maximum in the Atlantic Ocean (600-800 m; see Figures 2B and 3A), about half of the phosphate occurs as "preformed phosphate," which was present when the water originally subducted from the surface to form the Antarctic Intermediate water layer, while the remainder occurs as regenerated phosphate (Redfield et al., 1963). Likewise, only a portion of the trace metal nutrients at depth are likely derived from regeneration of settling biogenic particles, while the remainder must occur as "preformed metal nutrients."

The deep water concentrations of both major nutrient elements $(\mathrm{N}, \mathrm{P}$, and $\mathrm{Si}$ ) and many longer-lived metal micro-nutrients $(\mathrm{Zn}$, $\mathrm{Cd}, \mathrm{Ni}$, and $\mathrm{Cu}$ ) are two- to fivefold higher in deep waters of the
North Pacific than the North Atlantic (Figures 2 and 3) because of large scale differences in the thermohaline circulation patterns between the Atlantic and Pacific oceans. In the Pacific the major water inflow occurs at depth where concentrations of nutrients and longer-lived nutrient metals are high (Broecker, 1991). Consequently, the Pacific acts as a nutrient trap and concentrates high levels of nutrients and longer-lived nutrient metals in its deeper waters (Broecker, 1991). The Atlantic, by contrast, has the opposite circulation pattern, with its major inflow at the surface where nutrients and metals are depleted, and its major outflow at depth, the North Atlantic Deep water. As might be expected, this circulation pattern tends to lower deep water concentrations of major nutrients and longer-lived nutrient metals.

Two trace metal nutrients with short ocean residence times (Mn and $\mathrm{Co}$ ), show the opposite pattern to $\mathrm{Cu}, \mathrm{Zn}, \mathrm{Cd}$, and $\mathrm{Ni}$, and have highest concentrations at or near the surface and lower deep water concentrations in North Pacific than in the North Atlantic (Figures 2H and 3D; Landing and Bruland, 1987; Jickells and Burton, 1988; Martin et al., 1989). The short residence times and 


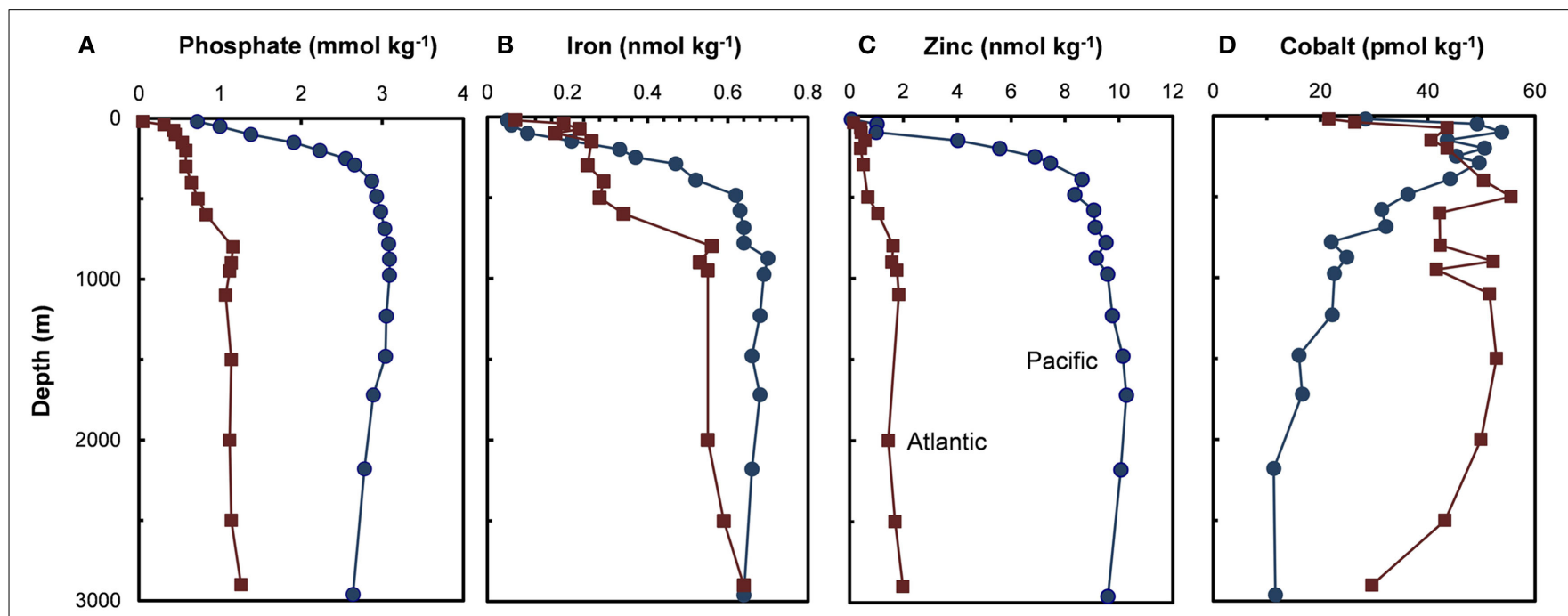

FIGURE 3 | Depth profiles for (A) phosphate and filterable concentrations of trace metal nutrients (B-D) (Fe, Zn, and Co) in the subarctic North Pacific Ocean (Ocean Station Papa, 50.0 $\mathrm{N}, 145.0 \mathrm{~W}$, August 1987; Martin et al., 1989) and the Northeast Atlantic (40 ${ }^{\circ} \mathrm{N}, 2^{2} \mathrm{~W}$, May 1989; Martin et al., 1993).

low concentrations in the older deep waters of the North Pacific are due to bacterially catalyzed oxidation of soluble $\mathrm{Mn}(\mathrm{II})$ and $\mathrm{Co}(\mathrm{II})$ to insoluble $\mathrm{Mn}(\mathrm{III}$ and IV) and $\mathrm{Co}(\mathrm{III})$ oxides, and subsequent removal via particulate aggregation and settling as the water advects along its flow path. Likewise, iron is scavenged from deep ocean waters by oxide formation and adsorption onto particles, but it is also avidly taken up by phytoplankton in surface waters. It has moderately short residence times ( $\sim 70-200$ years) and shows similar deepwater concentrations in the North Atlantic and Pacific (Johnson et al., 1997; Figure 3B). It exhibits surface depletion and increasing concentrations with depth in iron-limited regions such as the subarctic Pacific and northeast Atlantic during spring (Figure 3B), but can show pronounced surface maxima in stratified ocean waters receiving high aeolian inputs (Bruland et al., 1994; Measures and Vink, 1999).

In contrast to the other nutrient metals, Mo occurs at essentially the same concentration (100-110 nM) independent of depth or ocean basin (Collier, 1985). Its concentration is roughly proportional to salinity and its lack of depletion in surface waters indicates minimal removal of Mo by marine plankton relative to its seawater concentration, which is orders of magnitude higher than surface levels of other trace metal nutrients (Figures 1 and 2).

\section{COMPLEXATION AND REDOX CHEMISTRY}

Trace metal nutrients in the ocean exist as a variety of different chemical species and forms, which strongly influences their biological uptake and biogeochemical cycling. All but Mo occur as cationic metal ions that are complexed to varying degrees by inorganic and organic ligands or are adsorbed onto or bound within various abiotic and biotic particles. Many of these metals ( $\mathrm{Fe}, \mathrm{Cu}$, $\mathrm{Mn}$, and $\mathrm{Co}$ ) occur in different oxidation states, which have different solubilities, binding strengths with organic ligands, ligand exchange kinetics, and biological availabilities. Consequently, the redox chemistry of these metals has a major influence on their chemical behavior, biological uptake, and biogeochemical cycling.
$\mathrm{Ni}, \mathrm{Zn}$, and $\mathrm{Cd}$ exist in oxygenated seawater as soluble divalent cations that are complexed to varying degrees by inorganic ligands $\left(\mathrm{Cl}^{-}, \mathrm{OH}^{-}\right.$, and $\mathrm{CO}_{3}^{2-}$; Byrne et al., 1988) and organic chelators. Only a small percentage of $\mathrm{Ni}$ is complexed by organic ligands ( $0-30 \%$; Saito et al., 2004), while $\sim 97 \%$ of the filterable zinc (Bruland, 1989) and $~ 63 \%$ of filterable cadmium (Bruland, 1992) is chelated in North Pacific surface waters by unidentified strong organic ligands present at low concentrations (Table 1). Similar strong chelation of $\mathrm{Zn}$ has been observed in the North Atlantic and in subantarctic waters (Ellwood and van den Berg, 2000; Ellwood, 2004). Based on Zn concentrations in filtered surface waters from the North Pacific (0.06-0.9 nM; Bruland, 1980) and organic complexation data (Bruland, 1989), the concentration of biologically available dissolved inorganic zinc species $\left(\mathrm{Zn}^{\prime}\right)$ can be as low as $1-2 \mathrm{pM}$ in surface ocean water, low enough to limit the growth of at least some algal species (Sunda and Huntsman, 1992, 1995a). However, in deep ocean waters (Bruland, 1989), and upwelled surface waters in the Southern Ocean (Baars and Croot, 2011), Zn concentrations exceed the concentration of strong $\mathrm{Zn}$ binding ligands, resulting in up to 1000 -fold increases in $\mathrm{Zn}^{\prime}$ levels (Table 1).

Manganese exists in seawater in three oxidation states: $\mathrm{Mn}(\mathrm{II})$, $\mathrm{Mn}(\mathrm{III})$, and $\mathrm{Mn}(\mathrm{IV})$. Insoluble $\mathrm{Mn}(\mathrm{III})$ and $\mathrm{Mn}(\mathrm{IV})$ oxides are the stable redox forms of this metal in oxygenated seawater, although $\mathrm{Mn}(\mathrm{III})$ also occurs as soluble chelates with organic ligands in some environments (e.g., hypoxic waters; Trouwborst et al., 2006). These oxides can be reduced chemically and photochemically to dissolved $\mathrm{Mn}(\mathrm{II})$, which is highly soluble and is not bound appreciably by organic ligands (Sunda and Huntsman, 1994). Although $\mathrm{Mn}(\mathrm{II})$ is unstable with respect to oxidation by molecular oxygen $\left(\mathrm{O}_{2}\right)$, the chemical kinetics of this reaction are exceedingly slow in seawater (with a half life of 500 years at $\mathrm{pH} 8.1$ ), allowing $\mathrm{Mn}(\mathrm{II})$ to persist despite its thermodynamic instability (Morgan, 1967). Enzymes present within the outer polysaccharide sheath of certain bacteria, catalyze $\mathrm{Mn}$ (II) oxidation to $\mathrm{Mn}(\mathrm{IV})$ 

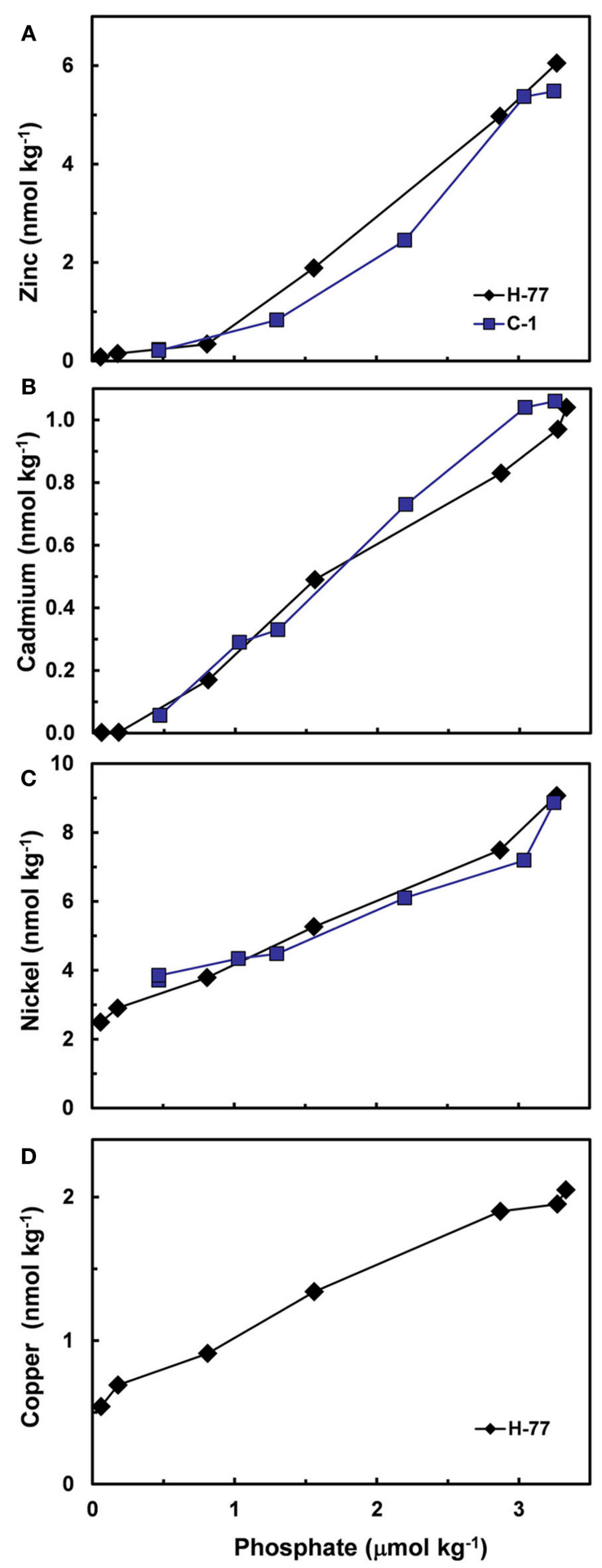

FIGURE 4 | Plots of concentrations of (A) $\mathrm{Zn}$, (B) Cd, (C) Ni, and (D) Cu vs phosphate within the nutricline of the northeast Pacific (upper 800-1000 m) at stations H-77 and C-I (Bruland, 1980).

oxides (Tebo et al., 2004; Anderson et al., 2009), a reaction which appears to account for virtually all $\mathrm{Mn}(\mathrm{II})$ oxidation in marine waters (Emerson et al., 1982; Sunda and Huntsman, 1988). The bacterial formation of Mn oxides, and their subsequent removal via particle settling results in short residence times and low-Mn concentrations in deep ocean waters as noted earlier (Figure $\mathbf{2 H}$ ). In the ocean's surface mixed layer, oxidation is greatly diminished owing to photo-inhibition of the Mn-oxidizing bacteria while Mn oxides are dissolved by photo-reduction to Mn(II; Sunda and Huntsman, 1988, 1994; Moffett, 1990). In the southwestern Sargasso Sea, Mn oxidation rates increased from undetectable levels $\left(<0.2 \%\right.$ day $\left.^{-1}\right)$ in the surface mixed layer to $3.3 \%$ day $^{-1}$ at $160 \mathrm{~m}$ just below the chlorophyll maximum (Sunda and Huntsman, 1988). By contrast, estimated rates of $\mathrm{Mn}$ oxide reductive dissolution decreased from $\sim 70 \%$ to $8.5 \%$ day $^{-1}$ over this same depth interval. The combination of decreased $\mathrm{Mn}$ (II) oxidation rates and increased rates of $\mathrm{Mn}$ oxide reductive dissolution caused a large decrease in Mn oxide concentration between $160 \mathrm{~m}$ and the surface and a concomitant four- to fivefold increase in dissolved $\mathrm{Mn}(\mathrm{II})$. Similar high concentrations of dissolved $\mathrm{Mn}$ (II) in surface seawater are widespread in the ocean (Figure $\mathbf{2 H}$ ), enhancing the supply of Mn needed to support algal photosynthesis (Sunda and Huntsman, 1988).

The chemical behavior of iron, biologically the most important trace metal nutrient, is arguably the most complex. In oxygenated seawater its stable oxidation state $\mathrm{Fe}$ (III) forms sparingly soluble iron hydroxide and oxide precipitates, whose solubility, lability, and biological availability decreases with oxide aging (Wells et al., 1991; Kuma et al., 1996; Lui and Millero, 2002; Yoshida et al., 2006). This oxide formation and the tendency of ferric ions to adsorb onto particle surfaces results in low deep ocean concentrations (0.4-0.8 nM; Johnson et al., 1997; Boyd and Ellwood, 2010) despite iron's high crustal abundance (it is the fourth most abundant element by weight). Most (>99.9\%) of the filterable Fe(III) in seawater is strongly bound to complex mixtures of organic ligands (Gledhill and van den Berg, 1994; Rue and Bruland, 1995; Buck and Bruland, 2007; Gledhill and Buck, 2012). This organic complexation minimizes iron adsorption and precipitation, and thus reduces iron removal from seawater by particulate scavenging processes (Johnson et al., 1997). Titrations utilizing ligand competition/cathodic stripping voltammetry reveal two classes of iron chelating ligands in near-surface seawater, a high-affinity class $\left(\mathrm{L}_{1}\right)$ and lower affinity class $\left(\mathrm{L}_{2}\right)$, with most of the filterable iron bound to the $\mathrm{L}_{1}$ class (Rue and Bruland, 1995; Cullen et al., 2006; Table 1). However in deeper water $(\geq 500 \mathrm{~m})$ only $\mathrm{L}_{1}$ class ligands are detected (Table 1), suggesting that they are produced by biological processes in the productive surface layers of the ocean. The two ligand classes and their iron chelates exist in both soluble (i.e., dissolved) and colloidal (0.02-0.4 $\mu \mathrm{m}$ size range) phases, with most of the ligands present in the soluble phase and some of the colloidal iron being inert to ligand exchange (Wu et al., 2001; Cullen et al., 2006).

The identity of the two ligand classes is yet to be determined (Vraspir and Butler, 2009; Gledhill and Buck, 2012). Many of the high-affinity ligands may be bacterial siderophores, strong ferric chelators produced by bacteria to solubilize iron and facilitate its intracellular uptake (Macrellis et al., 2001). Individual siderophores, largely in the hydroymate class, have been identified in ocean waters, but their concentrations account for only a few percent of the strong iron-binding ligands (Mawji et al., 2008, 
Table 2 | Comparison of slopes of nutrient metal to phosphate plots for station H-77 (Bruland, 1980) in the northeast Pacific with metal:P ratios in net plankton (Martin et al., 1976) and metal:C ratios in cultured marine algae.

\begin{tabular}{|c|c|c|c|c|c|c|c|c|}
\hline Metal & $\begin{array}{l}\text { Depth } \\
\text { range }(\mathrm{m})\end{array}$ & $\begin{array}{l}\text { P range } \\
(\mu \mathrm{M})\end{array}$ & $\begin{array}{l}\text { M vs P slope } \\
\left(\mathrm{mmol} \mathrm{mol}^{-1}\right)\end{array}$ & $\begin{array}{l}\text { Intercept } \\
\text { (nM) }\end{array}$ & $\mathrm{R}^{2}(n)$ & $\begin{array}{l}\text { M:P of net plankton } \\
\left(\mathrm{mmol} \mathrm{mol}^{-1}\right)\end{array}$ & $\begin{array}{l}\text { M:C from slopes* } \\
(\mu \mathrm{mol} \mathrm{mol}-1)\end{array}$ & $\begin{array}{l}\text { M:C in cultured } \\
\text { algae }\end{array}$ \\
\hline $\mathrm{Zn}$ & $185-780$ & $0.81-3.27$ & $2.32 \pm 0.06$ & $-1.62 \pm 0.14$ & $0.998(4)$ & $1.9 \pm 1.6$ & $22.2 \pm 0.6$ & \\
\hline $\mathrm{Cd}$ & $75-975$ & $0.18-3.33$ & $0.32 \pm 0.01$ & $-0.06 \pm 0.03$ & $0.994(6)$ & $0.43 \pm 0.14$ & $3.0 \pm 0.1$ & $2.5-4.1^{\ddagger}$ \\
\hline $\mathrm{Ni}$ & $0-780$ & $0.06-3.27$ & $1.93 \pm 0.10$ & $2.36 \pm 0.20$ & $0.989(6)$ & $0.47 \pm 0.26$ & $18.2 \pm 1.0$ & \\
\hline $\mathrm{Cu}$ & $0-975$ & $0.06-3.33$ & $0.44 \pm 0.02$ & $0.57 \pm 0.04$ & $0.992(7)$ & $0.41 \pm 0.13$ & $4.2 \pm 0.2$ & $4.4 \pm 0.6^{\S}$ \\
\hline
\end{tabular}

*Based on a C:P for marine plankton of 106 (Redfield et al., 1963).

'Mean and range based on mean and range of [ $\left.Z n^{\prime}\right]$ computed from the Zn chelation data of Bruland(1989; see Table 1) and the Zn:C vs [Zn'] relationship for the oceanic diatom Thalassiosira oceanica (Figure 5).

${ }^{\S}$ Based on the mean Cu:C in the diatoms T. oceanica and T. pseudonana, and the coccolithophore Emiliana huxleyi at the mean log [Cu'] in northeast Pacific ocean water (-11.8, see Table 1; Sunda and Huntsman, 1995c).

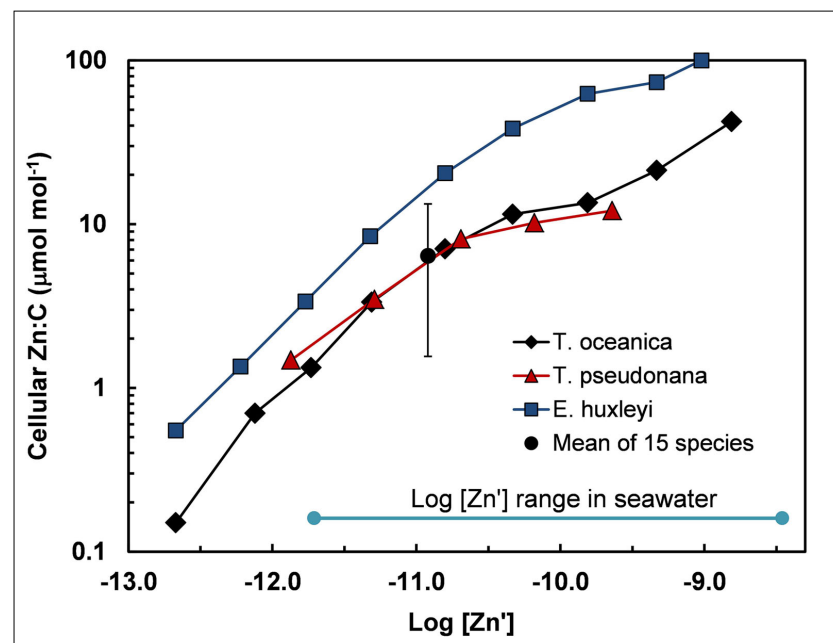

FIGURE 5 | Cellular Zn:C vs log [Zn'] in the oceanic diatom Thalassiosira oceanica, the coastal diatom $T$. pseudonana, and the oceanic coccoclithophore Emiliania huxleyi in seawater at $20^{\circ} \mathrm{C}$ based on data from Sunda and Huntsman (1995a). These results are compared with the mean and range (errors bars) of $\mathrm{Zn}: \mathrm{C}$ measured at the same temperature and a single $\left[Z^{\prime}{ }^{\prime}\right]$ in 15 different species of marine eukarotic phytoplankton from five major algal groups (Ho et al., 2003). The log [Zn'] range for ocean water is shown based on data of Bruland (1989) (Table 1).

2011; Velasquez et al., 2011). The low measured abundance of identifiable siderophores, however, may largely reflect our inability to quantitatively isolate other more-abundant classes of marine siderophores (e.g., catecholates and carboxylates) or reflect the presence of a large number of yet to be identified siderophores released by marine bacteria (Velasquez et al., 2011; Gledhill and Buck, 2012). There is also evidence that humic substances comprise at least some of the iron-binding ligands in coastal and deep ocean water and that many of these ligands may be derived from rivers and sedimentary sources (Laglera and van den Berg, 2009; Laglera et al., 2011). Other iron ligands with weak to moderate binding strengths are released from biological sources (e.g., grazing, viral lysis, and algal or bacterial secretion) and include porphyrins (Hunter and Boyd, 2007; Vong et al., 2007), acidic polysaccharides (Hassler et al., 2011a,b), and secreted chelating compounds such as domoic acid (Rue and Bruland, 2001).

Ferric iron can be reduced in seawater to highly soluble $\mathrm{Fe}(\mathrm{II})$ (ferrous iron) by several processes, including, biological reduction at cell surfaces (Maldonado and Price, 2001; Shaked et al., 2005), direct photolysis of ferric chelates (Kuma et al., 1992; Barbeau et al., 2001; Barbeau, 2006), reduction by photochemically or biologically produced superoxide radicals $\left(\mathrm{O}_{2}^{-}\right.$; Voelker and Sedlak, 1995; Rose et al., 2005; Kustka et al., 2005), or reduction within $\mathrm{O}_{2}$ depleted zones in organic particles or aggregates (Balzano et al., 2009). As a result up to $64 \%$ of the filterable iron in near-surface seawater occurs as Fe(II), with the highest percentage observed during daytime near the surface, suggesting a largely photochemical or algal source (Waite et al., 1995; Croot et al., 2008; Roy et al., 2008; Shaked, 2008; Sarthou et al., 2011). Because $\mathrm{Fe}$ (II) binds much more weakly to organic ligands than $\mathrm{Fe}(\mathrm{III})$ and because direct photolysis of ferric chelates involves oxidation and degradation of the ligand, the photo-reduction or biological reduction of chelated-Fe(III) often results in dissociation of $\mathrm{Fe}$ (II) from the chelate (Barbeau, 2006; Figure 6). The resulting soluble $\mathrm{Fe}(\mathrm{II})$ is unstable in the presence of $\mathrm{O}_{2}$, and is re-oxidized to dissolved $\mathrm{Fe}(\mathrm{III})$ hydrolysis species [ $\left.\mathrm{Fe}\left(\mathrm{III}^{\prime}\right)^{\prime}\right]$, which are then re-chelated by organic ligands (Sunda, 2001). Because $\mathrm{Fe}(\mathrm{II})^{\prime}$ and $\mathrm{Fe}(\mathrm{III})^{\prime}$ are continuously produced during redox cycling, elevated steady state concentrations of each are often established (Sunda and Huntsman, 2003), with Fe(II) residence times that increase with decreasing temperature, $\mathrm{pH}$, and concentrations of oxidants (primarily $\mathrm{O}_{2}$; Santana-Casiano et al., 2005). In air-equilibrated seawater at $\mathrm{pH} 8.0$, computed residence times for $\mathrm{Fe}(\mathrm{II})^{\prime}$ range from $3.2 \mathrm{~h}$ at $0^{\circ} \mathrm{C}$ to $2.2 \mathrm{~min}$ at $30^{\circ} \mathrm{C}$ (Santana-Casiano et al., 2005). There is evidence for Fe(II) chelation by unidentified organic ligands, which retards oxidation rates in some regions (Croot et al., 2008; Roy et al., 2008) and increases them in others (Roy and Wells, 2011), apparently linked to differences in the chemical nature of the complexing ligands. The nature and degree of organic complexation of $\mathrm{Fe}$ (II) needs to be quantified as it not only affects redox cycling of iron, but may also influence iron uptake by phytoplankton (Shaked and Lis, 2012). 


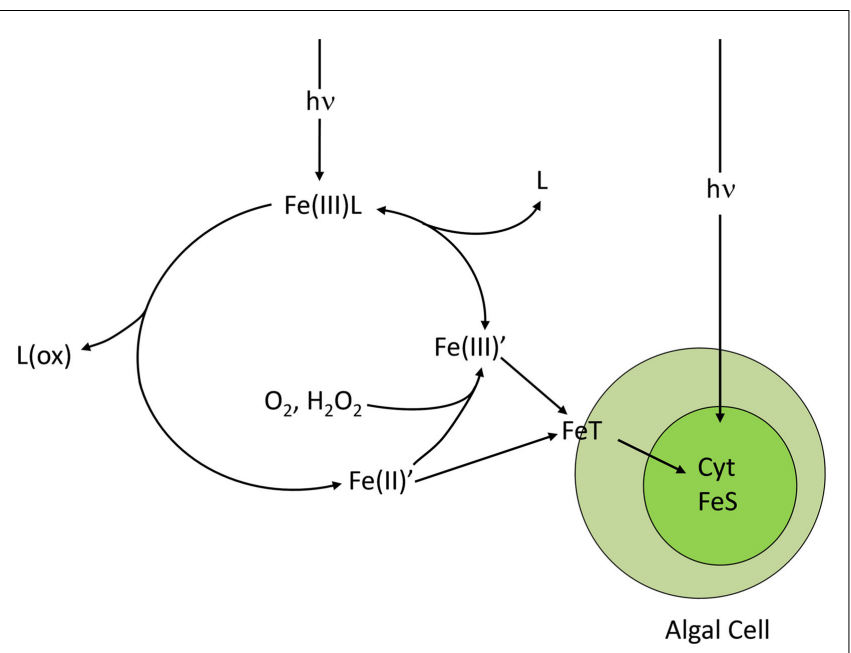

FIGURE 6 | Photo-redox cycling of ferric chelates (Fe(III)L), such as photoactive siderophore complexes. The cycle is initiated by the absorption of light by the ferric chelate and a subsequent photolytic reaction in which the iron is reduced to Fe(II) and the ligand is oxidized. The Fe(II) dissociates from the degraded chelate to give dissolved inorganic ferrous species (Fe(II)') which are then rapidly oxidized to dissolved inorganic ferric hydrolysis species (Fe(III)') by molecular oxygen and hydrogen peroxide. The $\mathrm{Fe}(\mathrm{III})^{\prime}$ is then re-chelated by the ligand to reform the ferric chelate. The cycle increases the uptake rate of iron by algal cells by increasing the steady state concentrations of biologically available Fe(II)' and Fe(III)'. The transport system T directly accesses $\mathrm{Fe}(\mathrm{II})^{\prime}$ and indirectly accesses $\mathrm{Fe}(\mathrm{III})^{\prime}$ by reduction to Fe(II)'. Once inside the cell, much of the iron is used for synthesis of cytochromes (Cyt) and Fe-S redox centers, needed in high amounts in photosynthesis.

Thus, iron undergoes a dynamic redox cycling in surface seawater, which can greatly enhance its biological availability to phytoplankton by increasing concentrations of highly available dissolved inorganic $\mathrm{Fe}(\mathrm{II})^{\prime}$ and $\mathrm{Fe}(\mathrm{III})^{\prime}$ species (Anderson and Morel, 1982; Sunda, 2001; Maldonado et al., 2005; Fan, 2008; Figure 6). The photochemical enhancement of iron uptake by phytoplankton increases with decreasing temperature because the photolysis of Fe(III) chelates should be largely insensitive to temperature while the oxidation rates of photochemically produced $\mathrm{Fe}(\mathrm{II})$ to dissolved $\mathrm{Fe}(\mathrm{III})^{\prime}$ slows as does the re-chelation of $\mathrm{Fe}(\mathrm{III})^{\prime}$ by organic ligands (Sunda and Huntsman, 2011; Figure 6). These slower reoxidation and re-chelation rates at lower temperatures increases the steady state concentrations of the highly biologically available $\mathrm{Fe}(\mathrm{II})^{\prime}$ and $\mathrm{Fe}(\mathrm{III})^{\prime}$ species in the presence of sunlight, as shown for ferric complexes with the synthetic chelator EDTA (Sunda and Huntsman, 2003, 2011). This enhanced photochemical effect should increase the availability of iron to phytoplankton in iron-limited polar regions such as the Southern Ocean, and without this effect, these regions might experience even more severe iron limitation.

Other micronutrient metals such as $\mathrm{Cu}$ and $\mathrm{Co}$ also exist in different oxidation states and are heavily chelated by organic ligands. Copper can exist in seawater as thermodynamically stable $\mathrm{Cu}(\mathrm{II})$, or as instable $\mathrm{Cu}(\mathrm{I})$ (Moffett and Zika, 1988). Most (>99\%) of the $\mathrm{Cu}$ in near-surface seawater is heavily chelated by strong organic ligands $\left(\log K_{\mathrm{Cu}^{\prime}, \mathrm{L} 1}=12-15\right)$ present at low concentrations (2-6 nM in open ocean waters), which decreases $\mathrm{Cu}(\mathrm{II})^{\prime}$ concentrations to very low levels $(0.001-10 \mathrm{pM}$; Coale and Bruland, 1990; Moffett, 1995; Moffett and Dupont, 2007; Buck et al., 2010; Table 1). Different electrochemical methods show consistent strong chelation of $\mathrm{Cu}$ in surface waters; however, in the deeper waters of the North Pacific (>200 m) the results diverge, with differential pulse anodic stripping voltammetry showing a complete loss of the strong $\mathrm{L}_{1}$ ligand class at depths below $200 \mathrm{~m}$, while ligand competition/cathodic stripping voltammetry shows continued strong complexation of copper by this ligand class down to at least $2500 \mathrm{~m}$ (Coale and Bruland, 1988, 1990; Moffett and Dupont, 2007). The reasons for these analytical differences are not known, but may be related to a change in the nature of the ligands and possibly the oxidation state of the bound copper between the surface and deeper waters (Moffett and Dupont, 2007).

$\mathrm{Cu}(\mathrm{II})$ can be reduced to $\mathrm{Cu}(\mathrm{I})$ by photochemical processes (Moffett and Zika, 1988), reduction at cell surfaces (Jones et al., 1987) or by reaction with chemical reducing agents, such as sulfur containing organic ligands (Leal and van den Berg, 1998). In surface waters, the resulting $\mathrm{Cu}(\mathrm{I})$ is re-oxidized by reaction with $\mathrm{O}_{2}$ on time scales of minutes and steady state $\mathrm{Cu}(\mathrm{I})$ concentrations can comprise $5-10 \%$ of the filterable copper (Moffett and Zika, 1988; Sharma and Millero, 1988). However, the effect of this redox cycling on the biological availability of copper is not known.

The chemistry of cobalt is also highly complex. Cobalt exists in seawater as soluble $\mathrm{Co}$ (II) or as $\mathrm{Co}$ (III), which forms insoluble oxides at the $\mathrm{pH}$ of seawater. The formation of these oxides appears to be microbially mediated and may be largely responsible for the removal of this metal from deep ocean waters (Tebo et al., 1984; Moffett and Ho, 1996; Figure 3D). Much of the filterable Co in seawater (up to100\%) is strongly bound to organic ligands (Ellwood and van den Berg, 2001; Saito and Moffett, 2001; Saito et al., 2005). The conditional stability constant(s) for the Co complexes is extremely high $\left(10^{15.6}\right.$ to $\left.\geq 10^{16.8} \mathrm{M}^{-1}\right)$, consistent with Co binding as kinetically inert Co(III) chelates (Saito et al., 2005).

\section{CELLULAR UPTAKE PROCESSES}

Trace metal nutrients, like major nutrients, are taken up intracellularly by specialized transport proteins on the cytoplasmic membrane of algal cells. Consequently, uptake rates generally follow Michaelis Menten enzyme kinetics

Uptake rate $=\frac{V_{\max }[\mathrm{M}]}{\left(K_{s}+[\mathrm{M}]\right)}$

as observed for Mn, Fe, Zn, and Cu (Sunda and Huntsman, 1986, 1998a; Hudson and Morel, 1990; Lane et al., 2008; Guo et al., 2010). In Eq. $1 V_{\max }$ is the maximum uptake rate, $[\mathrm{M}]$ is the concentration of chemical species that react with receptor sites on the transport protein (and thus are bioavailable by definition), and $K_{\mathrm{s}}$ is the $[\mathrm{M}]$ at which half of the transport sites are bound to the nutrient metal and the uptake rate is half of $V_{\max }$. Virtually all of these proteins act as pumps and require energy for intracellular transport. With some exceptions, the binding of metals to the receptor sites on these proteins is determined by the concentration of free aquated metal ions or in many cases, the concentration of kinetically labile dissolved inorganic species, $\mathrm{M}^{\prime}$ (aquated metal 
ions and inorganic complexes with $\mathrm{Cl}^{-}, \mathrm{OH}^{-}$, and $\mathrm{CO}_{3}^{2-}$; Hudson and Morel, 1993; Sunda and Huntsman, 1998b). Thus, chelation by organic ligands generally decreases metal uptake and chemical speciation is extremely important in regulating the cellular uptake of metals (Hudson, 1998).

Although Eq. 1 is relatively simple, its application is not entirely straight forward. One complicating factor is that the relevant substrate concentration, $[\mathrm{M}]$, is that at the surface of the cell membrane, which can be much less than that in bulk seawater in cases where the uptake rate approaches the maximum rate of diffusive flux of available metal species to the cell surface (Hudson and Morel, 1993). This indeed occurs for uptake of $\mathrm{Zn}$ and $\mathrm{Co}$ (II) by small diatoms and coccolithophores (3.5-6 $\mu \mathrm{m}$ diameter) at low $\mathrm{Zn}^{\prime}$ and $\mathrm{Co}^{\prime}$ concentrations (Sunda and Huntsman, 1995a; Figure 7). Since diffusive flux per unit of cell biovolume varies with the inverse square the cell diameter, diffusion limitation of uptake intensifies substantially as the cell size increases, and can be a major impediment for the uptake of some nutrient metals (Zn, Co, Fe) in larger cells (Hudson and Morel, 1993; Sunda and Huntsman, 1995a; Sunda, 2001). Another complicating factor is

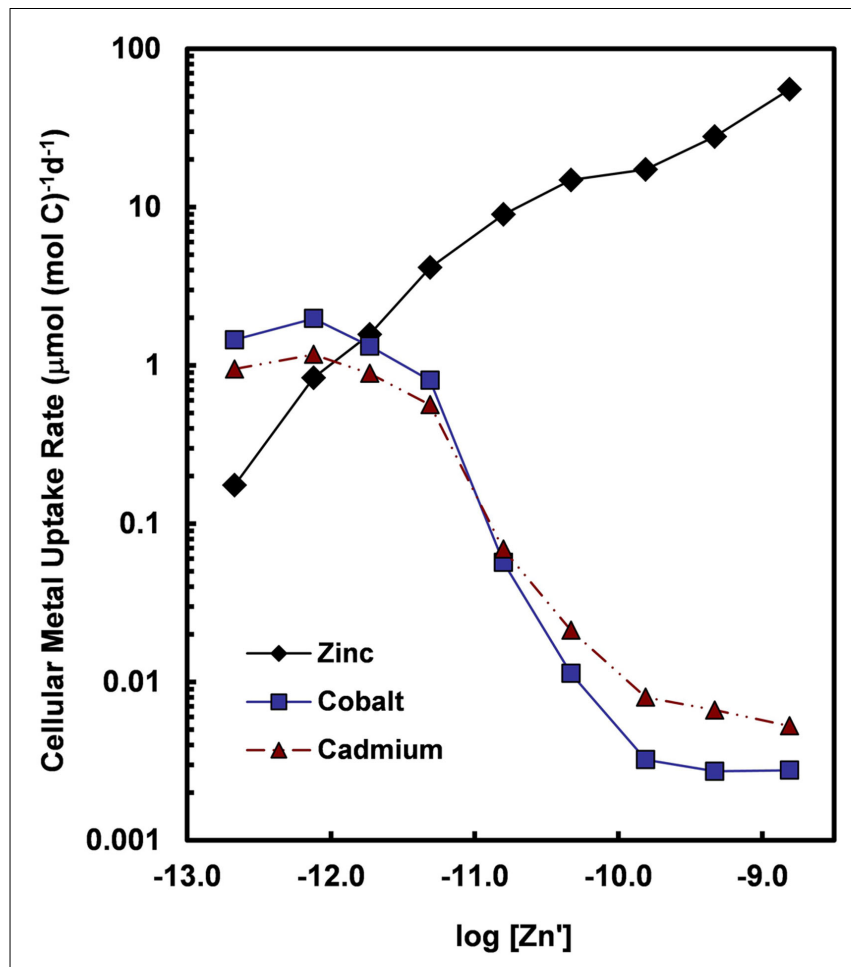

FIGURE 7 | Cellular uptake rates for Zn, Co, and Cd (normalized per mol of cell carbon) for the oceanic diatom Thalassiosira oceanica plotted as a function of the $\log _{10}$ of the molar concentration of dissolved inorganic zinc species $\left(\mathbf{Z n}^{\prime}\right)$. Concentrations of $\mathrm{Cd}^{\prime}$ and $\mathrm{Co}^{\prime}$ were held constant at 2.7 and $1.5 \mathrm{pM}$, respectively, within the range of values for near-surface ocean water (Bruland, 1992; Saito et al., 2004). Uptake rates for $\mathrm{Cd}$ and $\mathrm{Co}$ increase by at least two orders of magnitude when $\mathrm{Zn}^{\prime}$ concentrations decrease below $10^{-10} \mathrm{M}$. The large increase in uptake rates reflect the induction of a high-affinity cellular transport system (or systems) for $\mathrm{Cd}$ and $\mathrm{Co}$ in response to declining intracellular $\mathrm{Zn}$ levels or transport of the two metals into the cell by an inducible high-affinity $\mathrm{Zn}$ transport system. Data are from Sunda and Huntsman (2000). that the $V_{\max }$ of metal uptake systems is often under negative feedback regulation by the cell and can decrease substantially with increases in $\left[\mathrm{M}^{\prime}\right]$ and intracellular metal pools (Sunda and Huntsman, 1992, 1998b). This behavior can be particularly problematic in fitting Eq. 1 to the results of short-term metal uptake experiments as the $V_{\max }$ of the transport system investigated can vary during the course of the experiment (Sunda and Huntsman, 1985, 1986, 1992). A final complicating factor is that the values of $K_{\mathrm{s}}$ can increase and $V_{\max }$ decrease with increasing concentrations of competing metals that bind with and are taken up intracellularly by the transport system, as occurs for $\mathrm{Cu}, \mathrm{Cd}$, and $\mathrm{Zn}$ inhibition of $\mathrm{Mn}$ uptake and $\mathrm{Cu}$ inhibition of $\mathrm{Zn}$ uptake (Sunda and Huntsman, 1996, 1998c). All of these complicating factors must be taken into account for the proper application of the Michaelis Menten equation to laboratory and field metal uptake data.

Uptake systems are highly variable and range from simple to highly complex depending on the chemical speciation of the metal, its biological demand (requirement) relative to its seawater availability, and the range of concentrations of available metal species. Uptake systems appear to be simplest for dissolved Mn(II), which is taken up in phytoplankton by a single high-affinity transport system $\left(K_{\mathrm{s}}=15-140 \mathrm{nM} \mathrm{Mn}^{\prime}\right)$ that is under negative feedback regulation (Sunda and Huntsman, 1985, 1986). In this negative feedback, as the concentration of $\mathrm{Mn}(\mathrm{II})^{\prime}$ decreases, the $V_{\max }$ of the transport system is increased to maintain relatively constant Mn uptake rates and intracellular Mn concentration. This constant regulated cellular Mn level is two to four times higher than that needed to support the maximum growth rate, providing a buffer against decreasing $\mathrm{Mn}^{\prime}$ concentrations $\left(\left[\mathrm{Mn}^{\prime}\right]\right)$ or increases in cellular demand, as occurs with decreasing light intensity (see below). At sufficiently low $\left[\mathrm{Mn}^{\prime}\right]$ the $V_{\max }$ values reach a maximum constant value and the cellular Mn uptake rate and intracellular Mn concentration decreases with further decreases in $\left[\mathrm{Mn}^{\prime}\right]$ causing Mn-limitation of growth rate.

Uptake systems for $\mathrm{Zn}, \mathrm{Cd}, \mathrm{Co}$, and $\mathrm{Cu}$ are more complex. Like that of $\mathrm{Mn}$ (II), algal uptake of these metals is believed to be related to the concentration of dissolved inorganic metal species $\left(\mathrm{M}^{\prime}=\mathrm{Zn}^{\prime}, \mathrm{Cd}^{\prime}, \mathrm{Co}^{\prime}\right.$, and $\left.\mathrm{Cu}^{\prime}\right)$ and metal chelates are generally not directly available for metal uptake, with the exception of some $\mathrm{Cu}$ chelates at low $\mathrm{Cu}^{\prime}$ levels (Hudson, 1998; Sunda and Huntsman, 1998b; Guo et al., 2010). The phytoplankton species examined to date have at least two separate $\mathrm{Zn}$ transport systems, a lowaffinity system whose $V_{\max }$ is relatively constant, and an inducible high-affinity system, whose affinity $\left(1 / K_{\mathrm{s}}\right)$ and $V_{\max }$ increase with decreasing $\mathrm{Zn}^{\prime}$ concentration $\left(\left[\mathrm{Zn}^{\prime}\right]\right)$ and decreasing intracellular Zn (Sunda and Huntsman, 1992). The low-affinity system has higher $V_{\max }$ and $K_{\mathrm{s}}$ values and transports $\mathrm{Zn}$ at high $\left[\mathrm{Zn}^{\prime}\right]$. The inducible high-affinity system is responsible for $\mathrm{Zn}$ uptake at low $\left[\mathrm{Zn}^{\prime}\right]$. At very low $\left[\mathrm{Zn}^{\prime}\right](<10 \mathrm{pM})$, Zn uptake approaches limiting rates for the diffusion of $\mathrm{Zn}^{\prime}$ species to the cell surface, and consequently the $\mathrm{Zn}$ uptake rate is proportional to $\left[\mathrm{Zn}^{\prime}\right]$ in the medium (Sunda and Huntsman, 1992, 1995a; Figure 7). Similar biphasic high and low-affinity uptake systems, whose high-affinity uptake system is under negative feedback regulation, are observed for $\mathrm{Cu}$ in an oceanic diatom (Guo et al., 2010). The existence of high and low-affinity transport systems results in sigmoidal relationships between uptake rates for $\mathrm{Zn}$ and $\mathrm{Cu}$ (and cellular $\mathrm{Zn}: \mathrm{C}$ and $\mathrm{Cu}: \mathrm{C}$ 
ratios) and $\mathrm{Zn}^{\prime}$ and $\mathrm{Cu}^{\prime}$ concentrations (Figures 4 and 7; Sunda and Huntsman, 1992, 1995a,c).

Co and sometimes Cd can metabolically substitute for $\mathrm{Zn}$ in many $\mathrm{Zn}$ enzymes such as carbonic anhydrase (Price and Morel, 1990; Lane and Morel, 2000; Xu et al., 2008). To facilitate this substitution, the uptake of these divalent metals is increased by over 100-fold in diatoms and coccolithophores with decreasing $\left[\mathrm{Zn}^{\prime}\right]$ in the external medium and decreasing cellular $\mathrm{Zn}$ (Figure 7; Sunda and Huntsman, 1995a, 2000). Uptake of Cd and Co by this inducible transport system (or systems) is down-regulated at high $\left[\mathrm{Zn}^{\prime}\right]$ and intracellular $\mathrm{Zn}$ levels (Figure 7). Under these conditions, $\mathrm{Cd}$ is taken up into the cell by the cellular $\mathrm{Mn}$ (II) transport system (Sunda and Huntsman, 1996, 2000) or a putative Fe(II) transport system (Lane et al., 2008), and consequently, is inversely related to concentrations of $\mathrm{Mn}(\mathrm{II})^{\prime}$ and $\mathrm{Fe}(\mathrm{II})^{\prime}$. Thus, cellular uptake of $\mathrm{Cd}$ in the ocean is regulated by complex interactions among dissolved concentrations of $\mathrm{Cd}^{\prime}, \mathrm{Zn}^{\prime}, \mathrm{Mn}(\mathrm{II})^{\prime}$, and $\mathrm{Fe}(\mathrm{II})^{\prime}$ (Sunda and Huntsman, 2000; Cullen and Sherrell, 2005; Lane et al., 2009). Likewise, since Co uptake is repressed at high [ $\left.\mathrm{Zn}^{\prime}\right]$, biological removal of Co often does not occur until after $\mathrm{Zn}$ is depleted, as observed in the subarctic Pacific (Figure 8; Sunda and Huntsman, 1995a).

Iron is the most limiting trace metal nutrient, and its chemistry is arguably the most complex. As noted earlier, iron is highly bound in seawater as ferric chelates and ferric ions associated with various particulate phases such as Fe(III) oxyhydroxides. Early evidence suggested that cyanobacteria and eukaryotic marine algae utilized fundamentally different uptake systems to access this bound iron (Wilhelm and Trick, 1994; Hutchins et al., 1999). Both cyanobacteria and heterotrophic bacteria were thought to utilize primarily siderophore uptake systems, in which high-affinity Fe(III)-binding ligands (siderophores) were released extracellularly, followed by intracellular uptake of the resulting ferric-siderophore chelates (Martinez et al., 2000; Sandy and Butler, 2009). Siderophore uptake systems are widespread in terrestrial and enteric bacteria, and may also be common in sedimentary and particle-associated marine bacteria (Sandy and Butler, 2009). However, recent genomic data from cultures and natural communities shows little evidence for proteins involved in siderophore biosynthesis or for cellular uptake of ferric-siderophore chelates in the picocyanobacteria (Synechococcus and Prochlorococcus) that often dominate open ocean phytoplankton communities, or by major oceanic $\mathrm{N}_{2}$-fixing cyanobacteria such as Trichodesmium or Crocosphaera (Hopkinson and Morel, 2009; Hopkinson and Barbeau, 2012). Instead these species possessed a high abundance of $\mathrm{Fe}^{3+}$ ATP binding cassette $(\mathrm{ABC})$ transporters, which can acquire iron from ligand exchange reactions with dissolved labile Fe(III) species such as $\mathrm{Fe}(\mathrm{III})^{\prime}$ (Hopkinson and Barbeau, 2012). A reductive step, however, may be required to free the iron from ferric chelates, prior to its uptake (Rose et al., 2005; Kranzler et al., 2011; Shaked and Lis, 2012), and many marine cyanobacteria also possess nonspecific metal transporters that transport $\mathrm{Fe}(\mathrm{II})$ and other divalent metals (Hopkinson and Barbeau, 2012). A coastal Synechococcus isolate produced a suite of siderophores (synechobactins), which like many other marine siderophores, are both photoreactive and amphiphilic (Ito and Butler, 2005). But how widespread
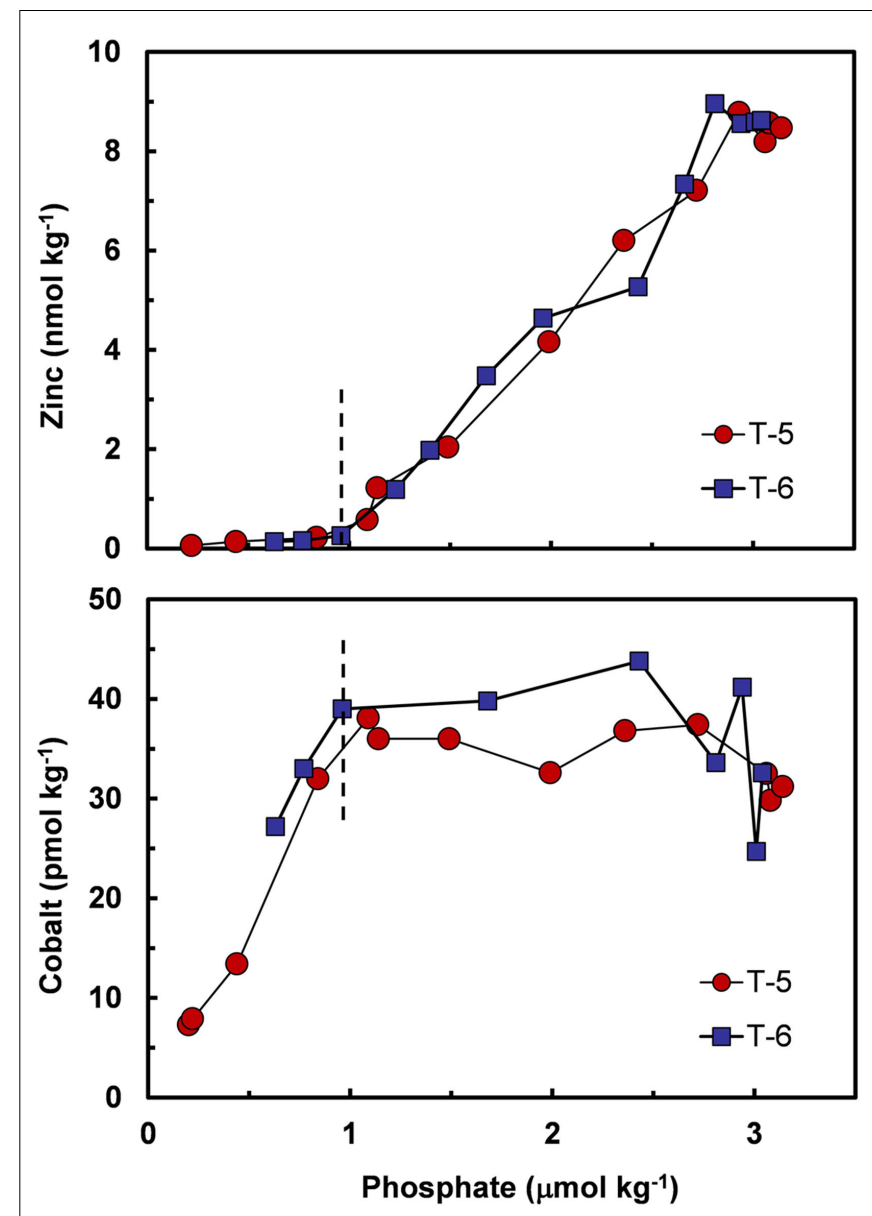

FIGURE 8 | Plots of filterable $\mathrm{Zn}$ and Co vs phosphate concentrations at two stations in the subarctic Pacific (Station T-5, 39.6 $\mathrm{N}, 140.8 \mathrm{~W}$ and Station T-6, 45.0 $\mathrm{N}, 142.9 \mathrm{~W}$, August 1987). The decrease in zinc with decreasing phosphate is caused by the simultaneous removal of both metals via cellular uptake and assimilation by phytoplankton. Cobalt decreases with decreasing phosphate only after zinc concentrations drop to very low levels $\left(<0.2 \mathrm{nmol} \mathrm{kg}^{-1}\right)$. This pattern is consistent with metabolic replacement of $\mathrm{Co}$ for $\mathrm{Zn}$, as observed in phytoplankton cultures (see Figure 5). Data plots after Sunda and Huntsman (1995a).

such siderophore production is in coastal cyanobacterial species is currently unknown (Hopkinson and Morel, 2009).

Eukaryotic phytoplankton do not appear to produce siderophores and there is little evidence for the direct cellular uptake of ferric-siderophore chelates (Sunda, 2001). Instead there is mounting evidence for the utilization of a high-affinity transport system that accesses a variety of $\mathrm{Fe}$ (III) coordination species (including $\mathrm{Fe}(\mathrm{III})^{\prime}$ and ferric chelates) via reduction to $\mathrm{Fe}(\mathrm{II} ; \mathrm{Mal}-$ donado and Price, 2001; Kustka et al., 2007; Amin et al., 2009; Strzepek et al., 2011). The released Fe(II)' binds to Fe(II) receptors on specific transmembrane proteins, which transport the iron into the cell. This intracellular transport involves the reoxidation of bound $\mathrm{Fe}$ (II) to $\mathrm{Fe}$ (III) by a copper protein (a multi-Cu oxidase; Maldonado et al., 2006). The ability of this transport system to access iron is dependent on the ease of reduction of 
ferric complex species, which is inversely related to the stability of the Fe(III) coordination complex (Maldonado and Price, 2001). Weakly complexed ferric hydrolysis species $\mathrm{Fe}(\mathrm{III})^{\prime}$ are reduced at orders of magnitude higher rates than strongly bound Fe-siderophore chelates, and are thus much more accessible for cellular uptake (Shaked et al., 2005; Morel et al., 2008). Likewise $\mathrm{Fe}$ (III) colloids are less available because of their slow diffusion kinetics within the cell's diffusive boundary layer and because interior ferric ions within the colloid are not readily accessible for reduction and subsequent release as dissolved $\mathrm{Fe}$ (II). As a consequence, iron uptake by this system is highly dependent on the chemical speciation of iron in seawater, and increases in dissolved $\mathrm{Fe}(\mathrm{II})^{\prime}$ or $\mathrm{Fe}(\mathrm{III})^{\prime}$ concentrations can considerably increase the biological availability of iron (Hudson and Morel, 1990; Morel et al., 2008). Photo-reductive dissociation of ferric chelates increases iron uptake by diatoms and other eukaryotic algae by increasing steady state $\mathrm{Fe}(\mathrm{II})^{\prime}$ and $\mathrm{Fe}(\mathrm{III})^{\prime}$ concentrations, as shown in culture experiments with photolabile ferric complexes with synthetic chelators (e.g., ethylenediaminetetraacetic acid, EDTA; Anderson and Morel, 1982; Sunda and Huntsman, 2011), marine siderophores (Barbeau et al., 2001; Amin et al., 2009), and sugar acids (Ozturk et al., 2004; Figure 6). Similarly, in an incubation experiment in the Southern Ocean, natural planktonic assemblages exhibited higher iron uptake rates from an added photoactive siderophore $\left({ }^{57} \mathrm{Fe}\right.$-aerobactin $)$ in the presence of sunlight than from a non-photoactive one $\left({ }^{57} \mathrm{Fe}\right.$-desferrioximine b; Buck et al., 2010).

In other recent iron uptake experiments in Southern Ocean waters, the pre-equilibration of ${ }^{55} \mathrm{Fe}$-labeled iron with the monosaccharide glucuronic acid increased the uptake of the radiolabeled iron by $\sim 2$-fold compared to the uptake observed when iron was added by itself (Hassler et al., 2011b). Similar enhanced uptake was observed with the addition of polysaccharides. These effects may be attributed to the formation of more biologically available weak organic chelates (Hassler et al., 2011b; Benner, 2011). However as noted above, dissolved ferric chelates and coordination complexes of adsorbed sugar acids and polysaccharides on the surfaces of iron oxyhydroxides can undergo photolysis and subsequent iron redox cycling, which should increase $\mathrm{Fe}(\mathrm{II})^{\prime}$ and $\mathrm{Fe}(\mathrm{III})^{\prime}$ concentrations (Kuma et al., 1992; Ozturk et al., 2004; Steigenberger et al., 2010), thereby providing a plausible alternative explanation for the observed results. The influence of mono and polysaccharides on iron chemistry, photochemical redox cycling, and bioavailability needs further investigation given the high abundance of these compounds in dissolved and colloidal marine organic matter and the widespread production of extracellular polysaccharides by marine phytoplankton and bacteria (Steigenberger et al., 2010; Benner, 2011; Hassler et al., 2011a,b).

\section{CELLULAR TRACE METAL QUOTAS AND METAL:CARBON RATIOS}

The trace metal concentration in algal cells normalized to cell volume or to cell carbon is not only dependent on the rates of intracellular metal uptake by transport systems (as discussed above) or adsorption on cell surfaces (Tovar-Sanchez et al., 2003), but also by the rate of biodilution by new biomass or cell carbon (Sunda and Huntsman, 1998b). The rate of change in cellular metal per mole of cell carbon $(\mathrm{dQ} / \mathrm{dt})$ equals the cellular uptake rate $V_{\mathrm{M}}$ (normalized to cell carbon) minus the rate of biodilution, which equals the net specific rate of C-fixation $\left(\mu_{c}\right)$ times the cellular metal:C ratio $(Q)$ :

$$
\frac{d Q}{d t}=V_{\mathrm{M}}-\mu_{\mathrm{c}} Q
$$

At steady state $\mathrm{d} Q / d t=0$ and the equation collapses to:

$Q=\frac{V_{M}}{\mu_{c}}$

Based on these equations, any factor that decreases growth rate but has no or a lesser effect on the metal uptake rate will increase the cellular metal:C ratio. This is seen in the response of cell Fe:C, $\mathrm{Mn}: \mathrm{C}$, and $\mathrm{Zn}: \mathrm{C}$ ratios in diatoms and dinoflagellates to light limitation of growth rate, where a $60-70 \%$ decrease in specific growth rate with a decrease in light intensity from 500 to $50 \mu \mathrm{mol}$ quanta $\mathrm{m}^{-2} \mathrm{~s}^{-1}$ increased the cell metal:C ratios by two- to threefold for a given $\left[\mathrm{M}^{\prime}\right]$ (Sunda and Huntsman, 1997, 1998c, 2005). For Mn and Fe, the higher Mn:C and Fe:C values helped the cells to photoacclimate to the low light conditions (see $\mathrm{Fe}$ and $\mathrm{Mn}$ sections below and Figure 9), and for $\mathrm{Zn}$, the higher $\mathrm{Zn}: \mathrm{C}$ ratio lowered the $\left[\mathrm{Zn}^{\prime}\right]$ needed to achieve maximum growth rate. However, as discussed previously, decreasing light can also decrease $\mathrm{Fe}$ and Mn uptake rates by decreasing $\left[\mathrm{Fe}^{\prime}\right]$ and $\left[\mathrm{Mn}(\mathrm{II})^{\prime}\right]$ levels, so the overall effect of lower light may still be to lower cell Fe:C and Mn:C ratios (Sunda and Huntsman, 2011). Temperature, another major growth-controlling factor, could potentially also affect cellular $\mathrm{M}: \mathrm{C}$ ratios, but in the one case examined to date, a temperature decrease from 20 to $10^{\circ} \mathrm{C}$ caused similar decreases in $V_{\mathrm{M}}$ and specific growth rate (at constant $\left[\mathrm{Fe}^{\prime}\right]$ ) so there was no effect on cellular Fe:C ratios (Sunda and Huntsman, 2011).

Equations 2 and 3 also have important implications for diel changes in cellular $\mathrm{M}: \mathrm{C}$ ratios. Carbon is photosynthetically fixed only during the day (and a portion is respired at night), but metal uptake can continue during both the light and dark period (Sunda and Huntsman, 2004). Consequently, cellular M:C ratios should decrease during the light period and increase at night. In agreement with this prediction, the cell $\mathrm{Fe}: \mathrm{C}$ ratio in an iron-limited diatom (Thalassiosira pseudonana) growing at a specific rate of 1.6 day $^{-1}$ decreased by $60 \%$ (from 63 to $25 \mu \mathrm{mol} \mathrm{Fe} \mathrm{mol} \mathrm{C}{ }^{-1}$ ) from the beginning to the end of the $14 \mathrm{~h}$ light period (Sunda and Huntsman, 2004). This result was for a metal chelate system (Fe-nitrilotriacetic acid) with no photochemical enhancement of $\left[\mathrm{Fe}^{\prime}\right]$ during the day, and the diel effect can be less or even reversed in marine systems with substantial photochemical redox cycling of iron (Sunda and Huntsman, 2004). For Zn, Co, Cd, and Ni, where photochemical cycling does not occur, the cellular M:C ratios should also decrease during the light period. This effect was observed in the diatom T. pseudonana where cell $\mathrm{Zn}$ :C decreased by twofold over the course of the light period (Sunda and Huntsman, 2004).

Metal uptake rates invariably increase with the concentration of available metal as observed for $\mathrm{Zn}$ uptake in the oceanic diatom Thalassiosira oceanica (Figure 7). For this diatom and the coccolithophore Emiliania huxleyi the specific growth rate is unaffected 

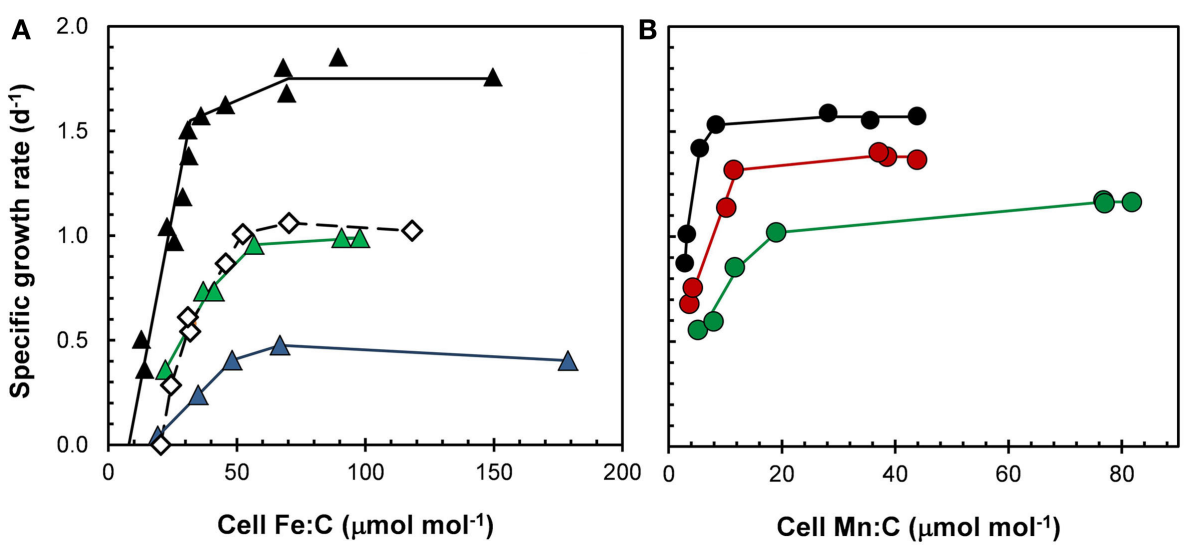

FIGURE 9 | Effect of light on cellular growth requirements for (A) iron and (B) manganese in the coastal diatom Thalassiosira pseudonana at $20^{\circ}$ C. (A) Relationships between specific growth rate and $\mathrm{Fe}: \mathrm{C}$ molar ratio for cells growing under a 14:10 h light:dark cycle at light intensities of 500 (black triangles), 85 (green triangles), and 50 (blue triangles) $\mu \mathrm{mol}$ photons $\mathrm{m}^{-2} \mathrm{~s}^{-1}$.
Open diamonds give data for cells growing at the highest light intensity $\left(500 \mu \mathrm{mol}\right.$ photons $\left.\mathrm{m}^{-2} \mathrm{~s}^{-1}\right)$ but a $50 \%$ shorter daily photoperiod (7 h). (B) Relationships between specific growth rate and cellular $\mathrm{Mn}: \mathrm{C}$ molar ratio for cell growing under a 14:10 h light:dark cycle at light intensities of 500 (black circles), 160 (red circles), and 90 (green circles) $\mu \mathrm{mol}$ photons $\mathrm{m}^{-2} \mathrm{~s}^{-1}$. over most the oceanic $\left[\mathrm{Zn}^{\prime}\right]$ range $\left(\log \left[\mathrm{Zn}^{\prime}\right]=-11.8\right.$ to -8.7$)$. Consequently, the cellular $\mathrm{Zn}: \mathrm{C}$ is proportional to the cellular $\mathrm{Zn}$ uptake rate, and increases with increasing $\left[\mathrm{Zn}^{\prime}\right]$ (see Figures 5 and 7).

Cellular metal:C ratios can vary substantially among species. The cell $\mathrm{Zn}: \mathrm{C}$ was two- to fivefold higher in the coccolitiophore $E$. huxleyi than the diatoms T. oceanica and T. pseudonana, depending on the $\left[\mathrm{Zn}^{\prime}\right]$ in the culture medium (Sunda and Huntsman, 1995a; Figure 5). Data of Ho et al. (2003) are consistent with those of Sunda and Huntsman (1995a) and show a 10-fold variation in $\mathrm{Zn}$ :C ratios in 15 different marine algal species representing five major algal groups (Figure 5). Even larger variations of 13-, 71-, and 50-fold, respectively, were observed for $\mathrm{Cu}: \mathrm{C}, \mathrm{Co}: \mathrm{C}, \mathrm{Cd}: \mathrm{C}$ ratios in these same algal species grown at a constant set of $\left[\mathrm{M}^{\prime}\right]$ values (Ho et al., 2003).

Recent advances in synchrotron X-ray fluorescence microscopy has allowed measurement of metal:P and metal:S ratios in single cells for a wide array of trace metals. As in the above culture data, large intriguing variations were observed in different algal cells and cell types present in the same water samples (Twining et al., 2004, 2010, 2011). In a recent study in the equatorial Pacific, diatoms had sevenfold higher Ni:P ratios and fourfold higher Fe-P and $\mathrm{Zn}: \mathrm{P}$ ratios than autotrophic flagellates (e.g., coccolithophores and dinoflagellates), but had 2.5-fold lower Co:P ratios (Twining et al., 2011).

Cells have the capacity to take up iron and other nutrient metals in far excess of that needed to support growth and metabolism, which helps them to take advantage of pulsed inputs, such as episodic increases in aeolian iron deposition associated with large desert dust storms (Sunda and Huntsman, 1995b; Marchetti et al., 2006). This "luxury" uptake also protects cells from future declines in metal availability as blooms develop or to increases in metabolic demand for iron and other metals linked to decreases in light or increases in temperature (Sunda and Huntsman, 2011). In addition, because of a certain degree of non-specificity of transport systems, many reactive trace metals (including metal nutrients, e.g., $\mathrm{Cu}$ and $\mathrm{Cd}$ ), can leak into cells via the transport systems for other metal nutrients such as $\mathrm{Mn}$ and Zn (Sunda and Huntsman, 1996, 1998c). Within the cell unchelated redox active metals such as iron and copper can mediate the formation of toxic reactive oxygen species (e.g., hydroxyl radicals via Fenten chemistry) and reactive metals such as $\mathrm{Cu}$, $\mathrm{Cd}$, and $\mathrm{Zn}$ can adventiciously bind with coordination sites of proteins or displace nutrient metals from their active sites in metalloproteins (Hartwig, 2001; Valko et al., 2005). Consequently, it is essential that "excess" concentrations of these metals be sequestered within algal cells to prevent metal toxicity or inhibition of metabolism (Finney and O'Halloran, 2003). Excess iron not occurring in metabolic proteins is bound within the iron storage protein ferritin in the pennate diatom Pseudo-nitzschia (Marchetti et al., 2009), and in Dps protein (another member of the ferritin protein family) in the $\mathrm{N}_{2}$-fixing cynaobacterium Trichodesmium (Castruita et al., 2006). Both of these algae have unusually high storage capacities for excess iron (Kustka et al., 2003a; Marchetti et al., 2006). Many marine picocyanobacteria (e.g., Synechococcus) possess genes for Dps or bacterioferritin iron storage proteins although the actual presence of these proteins has not yet been verified (Scanlan et al., 2009). Other marine eukaryotic phytoplankton such as centric diatoms also have substantial capacities to store excess intracellular iron (Sunda and Huntsman, 1995b), but the means by which they do so remains unclear.

High intracellular levels of $\mathrm{Cd}$ or $\mathrm{Cu}$ in a variety of eukaryotic phytoplankton are bound by phytochelatins, a set of sulfhydryl containing chelating ligands found in terrestrial plants, microalgae, and fungi. These ligands consist of small polymers of glutathione with the structure $(\gamma$-glutamate-cysteine) $n$-glycine, where $n=2-11$ (Ahner et al., 1995; Ahner and Morel, 1995; Ahner et al., 1997). Although low basal levels of these cellular chelators exist in cells, the cellular synthesis of phytochelatins is up-regulated by exposure to high concentrations of toxic nutrient or nonnutrient metals (e.g., $\mathrm{Cd}, \mathrm{Cu}$, or $\mathrm{Hg}$ ) or low levels of competing 
metal nutrients such as $\mathrm{Zn}$ or $\mathrm{Mn}$, which promote increased cellular Cd or Cu uptake (Ahner et al., 1998; see Figure 7).

\section{METABOLIC METAL REQUIREMENTS AND THEIR RELATION TO OTHER LIMITING RESOURCES}

Trace metal nutrients are essential for the metabolism, growth, and reproduction of all marine phytoplankton. They play essential roles in photosynthetic C-fixation, respiration, $\mathrm{N}_{2}$-fixation, and the uptake and metabolic assimilation of major nutrient elements (N, P, and $\mathrm{C})$. Thus the growth requirements of specific metals are influenced by the availability of light and the concentration and chemical forms of inorganic carbon, phosphorus and nitrogen species. Of the trace metal nutrients, iron is needed in the greatest amount for algal growth and most frequently limits the growth of marine phytoplankton. It serves essential metabolic functions in photosynthetic electron transport, respiration, nitrate and nitrite reduction, sulfate reduction, $\mathrm{N}_{2}$-fixation, and detoxification of reactive oxygen species such as superoxide radicals and hydrogen peroxide (Raven, 1988; da Silva and Williams, 1991; Raven et al., 1999).

The major requirement for iron in phytoplankton and likely all phototrophs is in the primary photochemical reactions of photosynthesis and associated photosynthetic electron transport (Raven, 1990; Strzepek and Harrison, 2004). To acclimate to low, subsaturating light conditions, phytoplankton increase the cellular concentration of photosynthetic pigments, reaction centers, and electron transport proteins and protein complexes, and to do this they need an increased amount of cellular iron (Raven, 1990). These iron-containing photosynthetic components include photosystem II (2-3 Fe), the cyt $f / b_{6}$ complex $(5 \mathrm{Fe})$, photosystem I $(12 \mathrm{Fe})$, cytochrome $c_{6}(1 \mathrm{Fe})$, and ferredoxin (2 Fe; Raven et al., 1999). This increased growth requirement for iron under low light conditions has been confirmed in culture experiments (Sunda and Huntsman, 1997, 2011; Strzepek and Harrison, 2004; Figure 9A). Such interactions between light and iron limitation can lead to iron-light co-limitation of algal growth in low light environments such as occur with deep vertical mixing during winter at higher latitudes (e.g., the subarctic Pacific and Southern Ocean; Maldonado et al., 1999) and in the deep chlorophyll maximum near the bottom of the photic zone in thermally stratified mid-ocean gyres (Sunda and Huntsman, 1997; Hopkinson and Barbeau, 2008). Algal cells acclimate similarly to a decrease in the photoperiod by increasing their photosynthetic pigments and cellular iron requirement for daily C-fixation and growth (Sunda and Huntsman, 2004, 2011; Figure 9A). Such day length effects could contribute to a higher level of iron limitation of phytoplankton growth during the shorter days of the fall than during the spring at high latitudes.

Iron is also needed for the assimilation of important chemical forms of nitrogen, which next to carbon is the second most abundant nutrient element in the cell. Nitrogen limits the growth and biomass of phytoplankton in roughly $60 \%$ of the ocean (Moore et al., 2002, 2004) and the overwhelming majority of biologically available fixed nitrogen in deep ocean reservoirs occurs as nitrate (Figure 2A). Nitrate is supplied to sunlit surface waters by upwelling and vertical mixing of deep ocean waters, but to utilize this substrate algal cells must first reduce it to ammonium, a process catalyzed by two iron-containing enzymes: nitrate reductase and nitrite reductase. In addition, both enzymatic reactions require the input of cellular energy (adenosine triphosphate, ATP) and reductant molecules (NADPH), and large amounts of cellular iron are needed for their photosynthetic production. Based on model calculations (Raven, 1988) and empirical measurements (Maldonado and Price, 1996), algal cells growing on nitrate require $\sim 50 \%$ more iron to support a given growth rate than do cells growing on ammonium. Consequently, iron can be especially limiting in oceanic upwelling systems (such as the equatorial and subarctic Pacific) where waters containing high nitrate concentrations, but low-iron, are advected to the surface (Martin and Fitzwater, 1988; Coale et al., 1996; Boyd et al., 2007). The low-iron concentrations favor the growth of small phytoplankton, which are rapidly grazed by microzooplankton, preventing blooms from developing, whose formation ultimately must be supported by inputs of upwelled nitrate (Price et al., 1991, 1994). The rapid grazing also supplies recycled ammonium which is more efficiently assimilated by the iron-limited cells. Thus the net population growth of such systems can be viewed as being co-limited by iron and nitrate due to the high iron requirement for nitrate utilization (Price et al., 1994).

A more important iron-nitrogen linkage is provided by the large metabolic requirement for iron in $\mathrm{N}_{2}$-fixation. All eukaryotic algae and most cyanobacteria are incapable of assimilating $\mathrm{N}_{2}$ which is present at a high concentration in the atmosphere (a mole fraction of 0.81) and in all ocean waters. Certain marine cyanobacteria, such as members of the genera Trichodesmium and Chrocosphera, are able to enzymatically reduce $\mathrm{N}_{2}$ to ammonium (referred to as $\mathrm{N}_{2}$-fixation; Zehr, 2011). $\mathrm{N}_{2}$-fixation requires very high amounts of cellular iron, and consequently, Trichodesmium growing on $\mathrm{N}_{2}$ as a nitrogen source require up to five times more cellular iron for growth than cells growing on ammonium (Kustka et al., 2003a). This much higher iron requirement is partly caused by the large amount of iron in the $\mathrm{N}_{2}$-fixation enzyme nitrogenase, and the low catalytic rate of this enzyme (Kustka et al., 2003b). However, it is also caused by the large amount of energy in the form of ATP needed to break the $\mathrm{N}_{2}$ triple bond (16 ATP per $\mathrm{N}_{2}$ molecule), which must be supplied either directly or indirectly from photosynthesis. As a result of the high metabolic iron cost and the low-iron concentrations in seawater, iron appears to limit $\mathrm{N}_{2}$-fixation in large regions of the ocean, and along with denitrification (respiratory reduction of $\mathrm{NO}_{3}^{-}$to $\mathrm{N}_{2}$ ), controls oceanic inventories of fixed nitrogen (Rueter et al., 1992; Falkowski, 1997; Kustka et al., 2003a; Sohm et al., 2011). Consequently, nitrogen is the primary limiting major nutrient in most ocean waters (Moore et al., 2004), while in lakes, where iron concentrations are much higher, phosphate is typically the primary limiting nutrient (Schindler, 1977). Because the low level of fixed nitrogen in the ocean is largely caused by iron limitation of $\mathrm{N}_{2}$-fixation, the ocean can be viewed as being co-limited by iron and nitrogen.

Ocean $\mathrm{N}_{2}$-fixation is largely restricted to warm tropical and subtropical waters (Moore et al., 2004; Zehr, 2011). $\mathrm{N}_{2}$-fixation varies regionally in these waters and is greatest in areas receiving high iron inputs from deposition of desert dust (or other continental sources), such as the subtropical North Atlantic, Arabian Sea, and the western margin of the Pacific (Sohm et al., 2011). And $\mathrm{N}_{2}$-fixation is lowest in the South Atlantic and South Pacific where continental inputs of iron are low. $\mathrm{N}_{2}$-fixation in regions with high 
atmospheric iron inputs tend to be dominated by Trichodesmium, which typically forms colonies $1-3 \mathrm{~mm}$ in diameter (Sohm et al., 2011). The colonies are able to intercept iron-containing dust particles and physically transport them to the colony's interior where the iron is solubilized and assimilated by unidentified reductive processes (Rueter et al., 1992; Rubin et al., 2011). The colonies can vertically migrate at velocities exceeding $3 \mathrm{~m} \mathrm{~h}^{-1}$, as enabled by the large colony size and variations in specific gravity (Walsby, 1992). This vertical movement increases the colony's encounter frequency with iron-containing dust particles, which further facilitates iron uptake (Sunda, 2001).

In the mid-ocean waters of the subtropical and tropical Pacific, continental inputs of iron are low as are iron concentrations, and here $\mathrm{N}_{2}$-fixation is dominated by much smaller unicellular cyanobacteria, such as Crocosphaera watsonii (Montoya et al., 2004; Sohm et al., 2011). The much smaller cell size (2-6 $\mu \mathrm{m}$ diameter), and attendant higher surface to volume ratios and higher diffusive flux of soluble iron to cell surfaces (per unit of biomass) help increase cellular iron uptake by these cyanobacteria in these low-iron waters (Sunda, 2001). In addition, recent proteomic data indicate that these cells undergo a large scale diel cellular cycle in which a portion of the iron-containing proteins involved in photosynthesis are degraded near the end of the light period and the iron released is then used to synthesize the iron-containing nitrogenase needed for nighttime fixation of $\mathrm{N}_{2}$, which is fueled by the ATP produced from respiratory consumption of stored carbohydrates (Saito et al., 2011). The nitrogenase proteins are then degraded near the end of the dark period and the liberated iron is reused to synthesize iron-containing photosynthetic proteins needed for Cfixation. This cellular strategy is energetically expensive, but solves two critical problems in iron-limited oceanic waters: it temporally separates $\mathrm{N}_{2}$-fixation and photosynthesis, and thereby avoids poisoning of nitrogenase enzyme complex by photosynthetically produced $\mathrm{O}_{2}$ (Zehr et al., 2001); and equally important, it reduces the cellular iron requirement for diazotrophic growth by $\sim 40 \%$ (Saito et al., 2011). The combination of higher iron uptake rates related to small cell size and the lower cellular iron requirement for diazotrophic growth provide a competitive advantage to Crocosphaera in low-iron oceanic waters, such as those in vast regions of the tropical and subtropical Pacific.

Due to iron limitation of C-fixation and $\mathrm{N}_{2}$-fixation in major regions of the ocean, iron plays a significant role in regulating carbon and nitrogen cycles in the ocean. It thus helps regulate the biological $\mathrm{CO}_{2}$ pump discussed earlier, which along with the physical $\mathrm{CO}_{2}$ pump, controls the ocean/atmosphere $\mathrm{CO}_{2}$ balance and $\mathrm{CO}_{2}$-linked greenhouse warming (Martin, 1990; Sigman and Boyle, 2000). There is evidence that climatically driven variations in the input of iron-rich continental dust to the ocean has played an important role in regulating glacial-interglacial climate cycles by influencing the intensity of the biological $\mathrm{CO}_{2}$ pump (Martin, 1990; Falkowski, 1997; Martínez-Garcia et al., 2011).

Manganese may influence the growth and species composition in certain low-Mn environments such as the subarctic Pacific and Southern Ocean, where Mn additions have been observed to stimulate algal growth in bottle incubation experiments (Buma et al., 1991; Coale, 1991). Mn occurs in the water oxidizing complex of photosystem II (which contains four Mn atoms), and thus is essential for oxygenic photosynthesis. Consequently, like iron, it is needed in higher amounts for algal growth at low light intensities (Raven, 1990; Sunda and Huntsman, 1998d; Figure 9B), such as the bottom of the photic zone where Mn concentrations are often lower than at the surface (Figure $2 \mathbf{H}$ ). Mn also occurs in superoxide dismutase, an antioxidant enzyme that removes toxic superoxide radicals, produced as byproducts of photosynthesis (Peers and Price, 2004; Wolfe-Simon et al., 2006). Because it has fewer metabolic functions, its cellular growth requirement is less than that for iron (Figure 9A, B).

Quantitative requirements for $\mathrm{Zn}$ in marine phytoplankton are similar to those for Mn (Sunda and Huntsman, 1995a, 1998d). Zn is needed in a variety of essential proteins needed for cell growth and replication (da Silva and Williams, 1991). It occurs in carbonic anhydrase (CA), an enzyme that catalyzes the reversible reaction:

$\mathrm{HCO}_{3}^{-}+\mathrm{H}^{+} \leftrightarrow \mathrm{CO}_{2}+\mathrm{H}_{2} \mathrm{O}$

Thus CA is critical to intracellular $\mathrm{CO}_{2}$ transport and fixation and is needed to support the cell's $\mathrm{CO}_{2}$ concentrating mechanism(s) (Badger and Price, 1994). Higher amounts of this enzyme are needed at low $\mathrm{CO}_{2}$ concentrations, leading to potential colimitation by $\mathrm{Zn}$ and $\mathrm{CO}_{2}$ in the ocean (Morel et al., 1994; Sunda and Huntsman, 2005). However, the $\sim 40 \%$ increase in $\mathrm{CO}_{2}$ in the atmosphere and surface ocean waters from the burning of fossil fuels makes $\mathrm{Zn}-\mathrm{CO}_{2}$ co-limitation less likely in the modern ocean than in pre-industrial times. Zinc occurs in zinc finger proteins and RNA polymerase, involved in DNA regulation and transcription, and in tRNA synthetase, involved in tRNA translation into proteins (da Silva and Williams, 1991). It is also found in alkaline phosphatase, needed to acquire orthophosphate via hydrolysis of organic phosphate esters, which dominate phosphate pools in surface ocean waters with low $\mathrm{P}$ concentrations (Lomas et al., 2010). Consequently, $\mathrm{Zn}$ and $\mathrm{P}$ may co-limit algal growth in ocean regions where both nutrients occur at low levels such as the Sargasso Sea (Wu et al., 2000; Shaked et al., 2006; Jakuba et al., 2008). Zn additions have been found to stimulate algal growth in bottle incubation experiments in the subarctic Pacific and in some coastal upwelling regimes along the eastern margin of the Pacific, but the effects were modest relative to those for added $\mathrm{Fe}$ (Coale, 1991; Crawford et al., 2003; Franck et al., 2003). However, $\mathrm{Zn}$ addition had a large effect on algal species composition, and preferentially stimulated the growth of the coccolithophore E. huxleyi (Crawford et al., 2003), which has an unusually large cellular uptake and growth requirement for $\mathrm{Zn} / \mathrm{Co}$ (Sunda and Huntsman, 1995a; see Figure 5). E. huxleyi and other coccolithophores are largely responsible for calcium carbonate formation and regulation of ocean water alkalinity, which in turn influences the air-sea exchange of $\mathrm{CO}_{2}$ (Dymond and Lyle, 1985). Thus, by affecting the growth of coccolithophores, $\mathrm{Zn}$ (and possibly Co, see below) could indirectly affect atmospheric $\mathrm{CO}_{2}$ and global climate.

$\mathrm{Co}$ and sometimes $\mathrm{Cd}$ can substitute for $\mathrm{Zn}$ in CA, alkaline phosphatase and other $\mathrm{Zn}$ enzymes, leading to complex interactions among the three metals in marine phytoplankton (Price and Morel, 1990; Sunda and Huntsman, 1995a; Xu et al., 2007; Jakuba et al., 2008; Saito and Goepfert, 2008; Figure 7). The presence of Cd in CA appears to explain its nutrient-like distribution in 
ocean waters (Figure 2E), and the identification of a unique CdCA enzyme in zinc-limited marine diatoms means that it functions as a micronutrient in these microalgae (Park et al., 2007; Xu et al., 2008). However, the substitution of $\mathrm{Zn}$ for $\mathrm{Cd}$ in this protein yields a more catalytically active enzyme (Xu et al., 2008), suggesting that $\mathrm{Zn}$ may have been evolutionarily the original metal center for this enzyme.

Co also occurs in vitamin $\mathrm{B}_{12}$, an essential vitamin required for growth of many eukaryotic algal species (Croft et al., 2005). This vitamin is synthesized by bacteria but not by eukaryotic phytoplankton, resulting in potential interactions among Co availability, $\mathrm{B}_{12}$-production by bacteria and $\mathrm{B}_{12}$-utilization by eukaryotic algae in the ocean (Croft et al., 2005; Bertrand et al., 2007; Panzeca et al., 2008). A specific requirement for Co not involving $B_{12}$ or a metabolic replacement for $\mathrm{Zn}$ is seen in marine cyanobacteria, including members of the genera Synechococcus and Prochlorococcus, but the biochemical basis for this is not known (Sunda and Huntsman, 1995a; Saito et al., 2002). A similar Co-requirement for optimal growth is observed in the bloom-forming prymnesiophytes $E$. huxleyi (Sunda and Huntsman, 1995a; Jakuba et al., 2008) and Chrysochromulina polylepis (Granéli and Risinger, 1994). Because of its unique requirement by cyanobacteria, Co may influence their growth in the ocean, as demonstrated by growth stimulation of Synechococcus by added Co in the Costa Rico upwelling dome (Saito et al., 2005).

Copper is also an essential micronutrient. It occurs along with iron in cytochrome oxidase, the terminal protein in respiratory electron transport that reduces $\mathrm{O}_{2}$ to $\mathrm{H}_{2} \mathrm{O}$ (da Silva and Williams, 1991). And it occurs in plastocyanin, which substitutes for the iron protein cytochrome $c_{6}$ in photosynthetic electron transport in oceanic diatoms (Peers and Price, 2006), some cyanobacteria (Scanlan et al., 2009), and the prymnesiophyte E. huxleyi (Guo et al., 2012). It is also an essential component of the high-affinity iron transport system of at least some eukaryotic algae (Maldonado et al., 2006; Kustka et al., 2007) and possibly some oceanic cynaobacteria (Guo et al., 2012). Because $\mathrm{Cu}$ is needed for Fe uptake and can metabolically substitute for $\mathrm{Fe}$, co-limitations can occur for $\mathrm{Cu}$ and $\mathrm{Fe}$, as observed in diatom cultures (Peers et al., 2005; Annett et al., 2008), and also in deck-board incubation experiments in iron-limited ocean water (Coale, 1991). These co-limitations are most prevalent for oceanic algal species, where substitutions of $\mathrm{Cu}$ proteins (plastocyanonin and $\mathrm{Cu} / \mathrm{Zn}-\mathrm{SOD}$ ) for iron enzymes (cytochrome $c_{6}$ and Fe-SOD) may help decrease the Fe growth requirements of oceanic species (Annett et al., 2008; Guo et al., 2012).

Nickel has only a minimal known usage in marine phytoplankton. It serves as the active metal center in urease, which hydrolyzes urea to ammonium. Consequently, it is essential for utilization of urea, an important nitrogen source in N-limited oceanic waters (Price and Morel, 1991). Recently a Ni-superoxide dismutase (NiSOD) was found to occur in marine cyanobacteria, a dominant group of picophytoplankton in open ocean waters (Dupont et al., 2008a,b). This finding may explain the unusually high Ni:P ratios in picoplankton (which were presumed to be cyanobacteria) in the equatorial Pacific (Twining et al., 2011). The Ni-SOD findings may be of significance evolutionarily as other forms of this critical antioxidant enzyme, which contain other metals in their catalytic centers (i.e., Fe-SOD, Mn-SOD, and $\mathrm{Cu} / \mathrm{Zn}-\mathrm{SOD}$ ), are the main SODs in eukaryotic algae and virtually all land plants and animals. Thus, the occurrence of Ni-SOD in oceanic cyanobacteria may help to reduce the biochemical demand for other micronutrient metals ( $\mathrm{Fe}, \mathrm{Zn}, \mathrm{Cu}$, and $\mathrm{Mn}$ ) which generally occur at lower concentrations than $\mathrm{Ni}$ in surface ocean waters (see Figures 2 and 3 ).

Mo occurs with Fe in several key $\mathrm{N}$-assimilation enzymes, including nitrogenase and nitrate reductase (da Silva and Williams, 1991). Thus, it is important in the ocean's nitrogen cycle; however, it is unlikely to limit algal growth due to the high concentration of molybdate ions in ocean water (105 nM; Collier, 1985). In addition to the Fe-Mo enzyme, some $\mathrm{N}_{2}$-fixing bacteria also contain other isoforms of nitrogenase, one that contains a homologous $\mathrm{Fe}$ $S$ cluster without Mo in its active center and another that contains Fe and vanadium (Boyd et al., 2011). Thus Mo is not absolutely essential for $\mathrm{N}_{2}$-fixation. However, the Fe-Mo enzyme is at least $50 \%$ more catalytically active than either of the other two isoforms which helps to minimize Fe-limitation of $\mathrm{N}_{2}$-fixation in the ocean (Anbar and Knoll, 2002).

\section{BIOLOGICAL FEEDBACK ON SEAWATER CHEMISTRY}

The interactions between trace metal nutrients and marine phytoplankton are reciprocal. While trace metals clearly influence the productivity and species composition of planktonic algae and bacteria, these microorganisms in turn have a profound effect on the chemistry and cycling of these metals in the ocean on a variety of time and spatial scales (Figure 1). One example of this interaction is the effect of algal uptake, particulate settling, and regeneration cycles on the vertical distribution and inter-ocean transfer of nutrient metals, as described earlier (Figures 2 and 3 ). In addition marine biota influence the chemical speciation of metals through a variety of processes: (1) the release of metal chelates and metal chelating ligands through zooplankton grazing, digestion, and defecation, and through viral lysis of cells and microbial degradation processes (Poorvin et al., 2004; Strzepek et al., 2005); (2) the active release of chelating compounds such as siderophores (Butler and Theisen, 2010) and polysaccharides (Hassler et al., 2011a), and (3) the reduction and oxidation of redox active metals ( $\mathrm{Fe}, \mathrm{Mn}, \mathrm{Co}$, and $\mathrm{Cu}$ ) by various biological processes. These processes include the reduction of iron and copper by cell surface reductases (Strzepek et al., 2011) or by biologically produced reducing agents (Rose et al., 2005), reduction of metals within particulate reducing microzones generated by microbial respiration, and oxidation of $\mathrm{Mn}(\mathrm{II}), \mathrm{Co}(\mathrm{II})$, and $\mathrm{Fe}(\mathrm{II})$ to their respective oxides by specific groups of bacteria (Moffett and Ho, 1996).

One of the most important effects of microorganisms on trace metal chemistry is in mediating the production of organic ligands that chelate $\mathrm{Fe}, \mathrm{Cu}, \mathrm{Zn}$, and $\mathrm{Co}$, especially in oceanic environments where the supply of terrestrial humic materials and other land-derived chelators is minimal. This chelation minimizes the loss of these essential metals by abiotic (and biotic) particulate scavenging and thereby minimizes their loss from ocean waters. The organic carbon needed for the in situ formation of these ligands is ultimately derived from algal photosynthesis, and thus the production of these ligands is at least indirectly dependent on marine algal productivity. However, many of these ligands 
appear to directly result from biological processes, and at least some directly facilitate biological uptake of metals. The release of siderophores clearly facilitates biological uptake of iron, as the releasing bacteria have specific transport systems for active uptake of iron-siderophore chelates (Butler and Theisen, 2010). However, most iron-siderophore chelates are orders of magnitude less available for algal uptake than is unchelated $\mathrm{Fe}^{\prime}$ (Shaked et al., 2005), and thus, in facilitating their own iron uptake, the bacteria could inadvertently lessen the uptake of iron by phytoplankton. Such an effect in turn could lessen photosynthetic production of organic carbon on which the bacteria depend for growth and survival. To avoid this conundrum, nature may have devised a clever mechanism to allow the bacteria to sequester iron for their own use, and at the same time make it more available to support photosynthetic fixation of carbon in sunlit surface ocean waters. Unlike the siderophores produced by soil and enteric bacteria, whose iron-siderophore chelates are unaffected by exposure to sunlight, the iron chelates of most siderophores produced by near-surface marine bacteria undergo photolysis owing to the presence of alpha hydroxy-carboxylate functional groups (Barbeau et al., 2003; Vraspir and Butler, 2009; Butler and Theisen, 2010). By contrast, these photoactive functional groups are relatively rare in terrestrial siderophores (Barbeau et al., 2003). The photolysis of the siderophore chelates can substantially increase the steady state concentrations of biologically available $\mathrm{Fe}(\mathrm{II})^{\prime}$ and $\mathrm{Fe}(\mathrm{III})^{\prime}$ species, and thereby increases the uptake of iron by phytoplankton, as directly shown in culture experiments with marine diatoms and dinoflagellates (Barbeau et al., 2001; Amin et al., 2009). In this way the bacteria are not only able to increase the availability of iron to themselves, but to phytoplankton in sunlit surface waters, thereby promoting the photosynthetic production of organic carbon needed for bacterial growth and reproduction, and ultimately for the production of siderophores. It is noteworthy that the marine bacteria found in close mutualistic association with marine dinoflagellates and cocolithophores produce a weaker iron-siderophore (vibrioferrin; $\log K_{\mathrm{Fe}^{\prime}}=10.9$ ), which contains two alpha hydroxy ligand groups, and is 10- to 20-times more photoreactive than the siderophores produced by free living marine bacteria (Amin et al., 2009). The in situ photolysis of this siderophore in the presence of attenuated sunlight increased the iron uptake rate in the dinoflagellate Scrippsiella trochoidea by 20 -fold but also increased the iron uptake rate by the producing bacterium (Marinobacter sp.) by 70\% (Amin et al., 2009). Here the photolysis reaction not only promoted iron uptake by the mutualistic algal partner, but also by the siderophore-producing bacterium.

There is also evidence that the strong ligands that tightly chelate $\mathrm{Cu}$ in seawater are produced by phytoplankton, especially cyanobacteria. In stratified waters of the North Pacific and Atlantic such strong $\mathrm{Cu}$-binding ligands often occur at highest levels near the deep chlorophyll maximum where cyanobacteria are abundant (Coale and Bruland, 1988, 1990; Moffett, 1995). The chelators appear to perform an important function of detoxifying copper. In the presence of the $\mathrm{Cu}$-chelators the average $\mathrm{Cu}^{\prime}$ in surface Northeast Pacific waters occurred at a non-toxic concentration (1.2 pM; Table 1) while in their absence $\mathrm{Cu}^{\prime}$ levels would have been 500 pM, a level toxic to many marine phytoplankton (Brand et al., 1986; Coale and Bruland, 1988). Ligands having similar Cubinding strength $\left(\log K_{\mathrm{Cu}^{\prime}}=11.8\right)$ as many of the strong chelators in surface seawater are produced by Synechococcus, an abundant group of oceanic cyanobacteria, that are particularly sensitive to copper toxicity (Brand et al., 1986; Moffett, 1995; Moffett and Brand, 1996). In experiments with Synechococcus, the production of the ligand was greatly enhanced in response to additions of toxic levels of $\mathrm{Cu}$, indicating that the cyanobacteria can actively modulate the availability and toxicity of $\mathrm{Cu}$ in their external environment via production of $\mathrm{Cu}$-chelators. Similar enhanced ligand production in response to added $\mathrm{Cu}$ was observed in cultures of eukaryotic phytoplankton, but the stability constants for $\mathrm{Cu}$ binding by these ligands $\left(\log K_{\mathrm{Cu}^{\prime}}=9.2-10.8\right)$ were lower than those for the chelators released by Synechococcus (Croot et al., 2000).

There is also evidence from laboratory and field experiments that the strong ligands that chelate Co in seawater are also produced by cyanobacteria, and that these ligands, like siderophores, facilitate the uptake of the chelated metal (Co) by these organisms (Saito et al., 2002, 2005).

Thus, trace metal nutrients and planktonic communities comprise an interactive system in the ocean in which each exerts a controlling influence on the other (Figure 1). On longer geological time scales, the feedback interactions between microorganisms and the chemistry and availability trace metals have been profound, and have substantially influenced the overall chemistry and cycling of major biological elements $(\mathrm{C}, \mathrm{O}, \mathrm{H}, \mathrm{N}$, and $\mathrm{S})$ in the ocean and the earth as a whole, and have had a major impact on the evolution of life on this planet (da Silva and Williams, 1991). Currently, the air we breathe and virtually the entire ocean contain high concentrations of dioxygen molecules $\left(\mathrm{O}_{2}\right)$, generated over billions of years from the release of $\mathrm{O}_{2}$ as a byproduct of oxygenic photosynthesis. Because of the presence of $\mathrm{O}_{2}$, the modern ocean is oxidizing, which as noted previously, limits the solubility of critical trace metal nutrients (Fe, Co, and $\mathrm{Mn}$ ) whose stable oxidation states under oxic conditions are sparingly soluble Fe(III) oxyhydroxides and insoluble $\mathrm{Co}$ (III) and $\mathrm{Mn}$ (IV) oxides. However, prior to the advent of oxygenic photosynthesis ca 3 billion years ago (Blankenship et al., 2007) and the appearance of $\mathrm{O}_{2}$ in the atmosphere 2.4-2.3 billion years ago (Bekker et al., 2004), the chemistry of the atmosphere and the ocean were far different from what exists today. There was no free $\mathrm{O}_{2}$ and the entire ocean, and earth's surface and atmosphere were chemically much more reducing (da Silva and Williams, 1991). Under these conditions the stable redox states of $\mathrm{Fe}, \mathrm{Mn}$, and Co were soluble $\mathrm{Fe}(\mathrm{II}), \mathrm{Mn}$ (II), and $\mathrm{Co}(\mathrm{II})$, and that of copper was $\mathrm{Cu}(\mathrm{I})$. Furthermore, the stable redox form of sulfur was sulfide (S[-II]), rather than sulfate (S[VI]), which occurs in present day seawater at a high concentration $(28 \mathrm{mM})$. The presence of moderate to high levels of sulfide greatly restricted the availability of $\mathrm{Zn}, \mathrm{Cu}, \mathrm{Mo}$, and $\mathrm{Cd}$, which form insoluble sulfide precipitates and biologically less available metal sulfide complexes; but it had a much a lesser impact on other metals [Mn(II), Fe(II), $\mathrm{Co}(\mathrm{II})$, and $\mathrm{Ni}(\mathrm{II})]$ which form much more soluble metal sulfides (da Silva and Williams, 1991; Saito et al., 2003). Thus, early life in the ocean likely evolved in an environment of high availability of $\mathrm{Fe}, \mathrm{Mn}, \mathrm{Co}$, and $\mathrm{Ni}$ and much lower availabilities of $\mathrm{Zn}, \mathrm{Mo}, \mathrm{Cu}$, and $\mathrm{Cd}$, contrasting the situation in the modern ocean. 
Given the utility of Fe as a versatile redox catalyst and its abundance in the earth's crust and early ocean, it is perhaps not surprising that this metal was utilized in the evolution of many of the central redox catalysts of life (Mauzerall, 2007). It occurs in high amounts in the redox centers of nitrogenase responsible for $\mathrm{N}_{2}$ reduction to $\mathrm{NH}_{3}$ and in the various cytochromes and $\mathrm{Fe}-\mathrm{S}$ redox centers involved in anoxygenic and oxygenic photosynthesis (da Silva and Williams, 1991; Raven et al., 1999). In addition, the abundant soluble $\mathrm{Mn}$ (II) in the ancient ocean was utilized in the evolution of the water oxidizing centers of photosystem II, which allowed cyanobacteria to utilize abundant water molecules as a photosynthetic electron donor, thereby freeing photosynthetic primary producers from the need to utilize much less abundant substrates such as sulfide or ferrous ions (Mauzerall, 2007). The resultant oxidation of $\mathrm{H}_{2} \mathrm{O}$ to $\mathrm{O}_{2}$ and burial of photosynthetically produced organic carbon in marine sediments and sedimentary rocks, slowly (over 1-2 billion years) oxidized $\mathrm{Fe}$ (II) to $\mathrm{Fe}$ (III) oxides and sulfide minerals to soluble sulfate, ultimately resulting in the buildup of free $\mathrm{O}_{2}$ first in the atmosphere and surface ocean beginning ca. 2.3 billion years ago, and gradually in the ocean as a whole by $\sim 500-600$ million years before present (Anbar and Knoll, 2002; Katz et al., 2007). The precipitation of ferric oxides

\section{REFERENCES}

Ahner, B. A., Kong, S., and Morel, F. M. M. (1995). Phytochelatin production in marine algae. 1 . An interspecies comparison. Limnol. Oceanogr. 40, 649-657.

Ahner, B. A., Lee, J. G., Price, N. M., and Morel, F. M. M. (1998). Phytochelatin concentrations in the equatorial Pacific. Deep Sea Res. 45, 1779-1796.

Ahner, B. A., and Morel, F. M. M. (1995). Phytochelatin production in marine algae. 2. Induction by various metals. Limnol. Oceanogr. 40, 658-665.

Ahner, B. A., Morel, F. M. M., and Moffet, J. W. (1997). Trace metal control of phytochelatin production in coastal waters. Limnol. Oceanogr. 42, 601-608.

Amin, S. A., Green, D. H., Hart, M. C., Küpper, F. C., Sunda, W. G., and Carrano, C. J. (2009). Photolysis of iron-siderophore chelates promotes bacterial-algal mutualism. Proc. Natl. Acad. Sci. U.S.A. 106, 17071-17076.

Anbar, A. D., and Knoll, A. H. (2002). Proterozoic ocean chemistry and evolution: a bioinorganic bridge? Science 297, 1137-1142.

Anderson, C. R., Johnson, H. A., Caputo, N., Davis, R. E., Torpey, J. W., and Tebo, B. M. (2009). Mn(II) oxidation is catalyzed by heme peroxidases in "Aurantimonas manganoxydans" strain SI85-9A1 and Erythrobacter sp strain SD-21. Appl. Environ. Microbiol. 75, 4130-4138.

Anderson, M. A., and Morel, F. M. M. (1982). The influence of aqueous iron chemistry on the uptake of iron by the coastal diatom Thalassiosira weissflogii. Limnol. Oceanogr. 27, 789-813.

Andreae, M. O., and Crutzen, P. J. (1997). Atmospheric aerosols: biogeochemical sources and role in atmospheric chemistry. Science 276, 1052-1058.

Annett, A. L., Lapi, S., Ruth, T. J., and Maldonado, M. T. (2008). The effects of $\mathrm{Cu}$ and $\mathrm{Fe}$ availability on the growth and $\mathrm{Cu}: \mathrm{C}$ ratios of marine diatoms. Limnol. Oceanogr. 53, 2451-2461.

Baars, O., and Croot, P. L. (2011). Speciation of dissolved zinc in the Atlantic sector of the southern ocean. Deep Sea Res II 58, 2720-2732.

Badger, M. R., and Price, G. D. (1994). The role of carbonic anhydrase in photosynthesis. Annu. Rev. Plant Physiol. Plant Mol. Biol. 45, 369-392.

Balzano, S., Statham, P. J., Pancost, R. D., and Lloyd, J. R. (2009). Role of microbial populations in the release of reduced iron to the water column from marine aggregates. Aquat. Microb. Ecol. 54, 291-303.

Barbeau, K. (2006). Photochemistry of organic iron(III) complexing ligands in oceanic systems. Photochem. Photobiol. 82, 1505-1516.

from the sea has resulted in the chronic Fe-limitation of C-fixation and $\mathrm{N}_{2}$-fixation that we currently observe in the ocean. However, this negative effect is more than offset by the large amount of biological energy produced by $\mathrm{O}_{2}$-dependent respiration utilized by all present day plants and animals and most aerobic microbes. Indeed the large amount of energy obtained from the respiratory reaction of $\mathrm{O}_{2}$ with organic molecules likely was essential for the development of multicellular forms of life, paving the way for the evolution of mammals, including man (Mauzerall, 2007). Furthermore, the release of $\mathrm{Zn}, \mathrm{Cu}, \mathrm{Mo}$, and $\mathrm{Cd}$ from insoluble sulfides and biologically unavailable sulfide complexes allowed for the proliferation of numerous enzymes utilizing these metals (including many $\mathrm{Zn}$ and $\mathrm{Cu}$ enzymes), many of which appear to have evolved following the appearance of free $\mathrm{O}_{2}$ (da Silva and Williams, 1991). Thus, evolution has involved a continuous feedback between biological systems and the surrounding chemical environment, with biological trace metal catalysts playing a central mediating role in this process.

\section{ACKNOWLEDGMENTS}

I thank Mark Vandersea for help in formatting the figures and Yeala Shaked, Christel Hassler, and Ken Bruland for useful comments.

Barbeau, K., Rue, E. L., Bruland, K. W., and Butler, A. (2001). Photochemical cycling of iron in the surface ocean mediated by microbial iron(III)-binding ligands. Nature 413, 409-413.

Barbeau, K., Rue, E. L., Trick, C. G., and Bruland, K. W., and Butler, A. (2003). Photochemical reactivity of siderophores produced by marine heterotrophic bacteria and cyanobacteria based on characteristic $\mathrm{Fe}(\mathrm{III})$ binding groups. Limnol. Oceanogr. 48, 1069-1078.

Behrenfeld, M. J., and Kolber, Z. S. (1999). Widespread iron limitation of phytoplankton in the South Pacific Ocean. Science 283, 840-843.

Bekker, A., Holland, H. D., Wang, P. L. Rumble, D., Stein, H. J., Hannah, J. L., Coetzee, L. L., and Beukes, N. J. (2004). Dating the rise of atmospheric oxygen. Nature 427, 117-120.

Benner, R. (2011). Loose ligands and available iron in the ocean. Proc. Natl. Acad. Sci. U.S.A. 108, 893-894.

Bertrand, E. M., Saito, M. A., Rose, J. M., Riesselman, C. R., Lohan, M. C., Noble, A. E., Lee, P. A., and DiTullio, G. R. (2007). Vitamin B-12 and iron colimitation of phytoplankton growth in the Ross Sea. Limnol. Oceanogr. 52, 1079-1093.

Blankenship, R. E., Sadekar, S., and Raymond, J. (2007). “The evolutionary transition from anoxygenic to oxigenic photosynthesis," in Evolution of primary production in the sea, eds
P. G. Falkowski and A. H. Knoll (Amsterdam: Elsevier), 21-35.

Boyd, E. S., Hamilton, T. L., and Peters, J. W. (2011). An alternative path for the evolution of biological nitrogen fixation. Front. Microbiol. 2:205. doi:10.3389/fmcb.2011.00205

Boyd, P. W., and Ellwood, M. J. (2010). The biogeochemical cycle of iron in the ocean. Nat. Geosci. 3, 675-682.

Boyd, P. W., Jickells, T., Law, C. S., Blain, S., Boyle, E. A., Buesseler, K. O., Coale, K. H., Cullen, J. J., de Baar, H. J. W., Follows, M., Harvey, M., Lancelot, C., Levasseur, M., Owens, N. P. J., Pollard, R., Rivkin, R. B., Sarmiento, J., Choemann, V., Smetacek, V., Takeda, S., Tsuda, A., Turner, S., and Watson, A. J. (2007). Mesoscale iron enrichment experiments 1993-2005: synthesis and future directions. Science 315, 612-617.

Boyle, E., Edmond, J. M., and Sholkovitz, E. R. (1977). The mechanism of iron removal in estuaries. Geochim. Cosmochim. Acta 41, 1313-1324.

Brand, L. E. (1991). Minimum iron requirements of marine phytoplankton and the implications for the biogeochemical control of new production. Limnol. Oceanogr. 36, 1756-1771.

Brand, L. E., Sunda, W. G., and Guillard, R. R. L. (1983). Limitation of marine phytoplankton reproductive rates by zinc, manganese and iron. Limnol. Oceanogr. 28, 1182-1198. 
Brand, L. E., Sunda, W. G., and Guillard, R. R. L. (1986). Reduction of marine phytoplankton reproduction rates by copper and cadmium. J. Exp. Mar. Biol. Ecol. 96, 225-250.

Broecker, W. S. (1991). The great ocean conveyor. Oceanography 4, 79-89.

Bruland, K. W. (1980). Oceanographic distributions of cadmium, zinc, nickel and copper in the North Pacific. Earth Planet. Sci. Lett. 47, 176-198.

Bruland, K. W. (1989). Complexation of zinc by natural organic ligands in the central North Pacific. Limnol. Oceanogr. 34, 267-285.

Bruland, K. W. (1992). Complexation of cadmium by natural organic ligands in the central North Pacific. Limnol. Oceanogr. 37, 1008-1017.

Bruland, K. W., and Franks, R. P. (1983). "Mn, Ni, Cu, $\mathrm{Zn}$ and $\mathrm{Cd}$ in the Western North Atlantic," in Trace Metals in Sea Water, eds C. S Wong, E. Boyle, K. W. Bruland, J. D. Burton, and E. D. Goldberg (New York: Plenum Press), 395-414.

Bruland, K. W., and Lohan, M. C. (2003). "Controls of trace metals in seawater," in Treatise on Geochemistry, eds D. H. Heinrich and $\mathrm{K}$. T. Karl (Oxford: Pergamon), 23-47.

Bruland, K. W., Orians, K. J., and Cowen, J. P. (1994). Reactive trace metals in the stratified central North Pacific. Geochim. Cosmochim. Acta 58, 3171-3182.

Buck, K. N., and Bruland, K. W. (2007). The physicochemical speciation of dissolved iron in the Bering Sea, Alaska. Limnol. Oceanogr. 52, 1800-1808.

Buck, K. N., Selph, K. E., and Barbeau, K. A. (2010). Iron-binding ligand production and copper speciation in an incubation experiment of Antarctic Peninsula shelf waters from the Bransfield Strait, Southern Ocean. Mar. Chem. 122, 148-159.

Buma, A. G. J., de Baar, H. J. W., Nolting, R. F., and van Bennekom, A. J. (1991). Metal enrichment experiments in the Weddell-Scotia Seas: effects of iron and manganese on various plankton communities. Limnol. Oceanogr. 36, 1865-1878.

Butler, A., and Theisen, R. M. (2010). Iron(III)-siderophore coordination chemistry: reactivity of marine siderophores. Coord. Chem. Rev. 254, 288-296.

Byrne, R. H., Kump, L. R., and Cantrell, K. J. (1988). The influence of temperature and $\mathrm{pH}$ on trace metal speciation in seawater. Mar. Chem. 25, 163-181.

Castruita, M., Saito, M., Schottel, P. C., Elmegreen, L. A., Myneni, S.,
Stiefel, E. I., and Morel, F. M. M. (2006). Overexpression and characterization of an iron storage and DNA-binding Dps protein from Trichodesmium erythraeum. Appl. Environ. Microbiol. 72, 2918-2924.

Charlson, R. J., Lovelock, J. E., Andreae, M. O., and Warren, S. G. (1987). Oceanic phytoplankton, atmospheric sulfur, cloud albedo and climate. Nature 326, 655-661.

Coale, K. H. (1991). Effects of iron, manganese, copper, and zinc enrichments on productivity and biomass in the subarctic Pacific. Limnol. Oceanogr. 36, 1851-1864.

Coale, K. H., and Bruland, K. W. (1988). Copper complexation in the northeast Pacific. Limnol. Oceanogr. 33, 1084-1101

Coale, K. H., and Bruland, K. W. (1990). Spatial and temporal variation of copper complexation in the North Pacific. Deep Sea Res. 47, 317-336

Coale, K. H., Fitzwater S. E., Gordon, R. M., Johnson, K. S., and Barber, R. T. (1996). Control of community growth and export production by upwelled iron in the equatorial Pacific Ocean. Nature 379, 621-624

Coale, K. H., Johnson, K. S., Chavez, F. P., Buesseler, K. O., Barber, R. T., Brzezinski M. A., Cochlan, W. P., Millero, F. J., Falkowski, P. G., Bauer, J. E., Wanninkhof, R. H., Kudela, R. M., Altabet, M. A., Hales, B. E., Takahashi, T., Landry, M. R., Bidigare, R. R., Wang, X., Chase, Z., Strutton, P. G, Friederich, G. E., Gorbunov, M.Y., Lance, V. P., Hilting, A. K., Hiscock, M. R., Demarest, M., Hiscock, W. T., Sullivan, K. F., Tanner, S. J., Gordon, R. M., Hunter, C. N., Elrod, V. A., Fitzwater, S. E., Jones, J. L., Tozzi, S., Koblizek, M., Roberts, A. E., and Herndon, J. (2004). Southern ocean iron enrichment experiment: carbon cycling in high- and low-Si waters. Science 304, 408-414.

Collier, R. W. (1985). Molybdenum in the northeast Pacific Ocean. Limnol. Oceanogr. 30, 1351-1354.

Crawford, D. W., Lipsen, M. S., Purdie, D. A., Lohan, M. C., Statham, P. J., Whitney, F. A., Putland, J. N., Johnson, W. K., Sutherland, N., Peterson, T. D., Harrison, P. J., and Wong, C. S. (2003). Influence of zinc and iron enrichments on phytoplankton growth in the northeastern subarctic Pacific. Limnol. Oceanogr. 48, 1583-1600.

Croft, M. T., Lawrence, A. D., RauxDeery, E., Warren, M. J., and Smith, A. G. (2005). Algae acquire vita$\min B_{12}$ through a symbiotic relationship with bacteria. Nature 438, 90-93.
Croot, P. L., Baars, O., and Streu, P. (2011). The distribution of dissolved zinc in the Atlantic sector of the Southern Ocean. Deep Sea Res. II 58, 2707-2719.

Croot, P. L., Bluhm, K., Schlosser, C., Streu, P., Breitbarth, E., Frew, R., and Van Ardelan, M. (2008). Regeneration of Fe(II) during EIFeX and SOFeX. Geophys. Res. Lett. 35 , L19606.

Croot, P. L., Moffett, J. W., and Brand, L. E. (2000). Production of extracellular ligands by eucaryotic phytoplankton in response to $\mathrm{Cu}$ stress. Limnol. Oceanogr. 45, 619-627.

Cullen, J. T., Bergquist, B. A., and Moffett, J. W. (2006). Thermodynamic characterization of the partitioning of iron between soluble and colloidal species in the Atlantic Ocean. Mar. Chem. 98, 295-303.

Cullen, J. T., and Sherrell, R. M. (2005). Effects of dissolved carbon dioxide, zinc, and manganese on the cadmium to phosphorus ratio in natural phytoplankton assemblages. Limnol. Oceanogr. 50, 1193-1204.

da Silva, J. J. R. F., and Williams, R. J. P. (1991). The Biological Chemistry of the Elements. Oxford: Clarenden Press.

Duce, R. A., and Tindale, N. W. (1991). Atmospheric transport of iron and its deposition in the ocean. Limnol. Oceanogr. 36, 1715-1726.

Dupont, C. L., Barbeau, K., and Palenik, B. (2008a). Ni uptake and limitation in marine Synechococcus strains. Appl. Environ. Microbiol. 74, 23-31.

Dupont, C. L., Neupane, K., Shearer J., and Palenik, B. (2008b). Diversity, function and evolution of genes coding for putative Nicontaining superoxide dismutases. Environ. Microbiol. 10, 1831-1843.

Dymond, J., and Lyle, M. (1985). Flux comparisons between sediments and sediment traps in the eastern tropical Pacific: implications for atmospheric $\mathrm{CO} 2$ variations during the Pleistocene. Limnol. Oceanogr. 30, 699-712.

Ellwood, M. J. (2004). Zinc and cadmium speciation in subantarctic waters east of New Zealand. Mar. Chem. 87, 37-58

Ellwood, M. J., and van den Berg, C. M. G. (2000). Zinc speciation in the Northeastern Atlantic Ocean. Mar. Chem. 68, 295-306.

Ellwood, M. J., and van den Berg, C. M. G. (2001). Determination of organic complexation of cobalt in seawater by cathodic stripping voltammetry. Mar. Chem. 75, 33-47.

Emerson, S., Kalhorn, S., Jacobs, L. Tebo, B. M., Nealson, K. H., and
Rosson, R. A. (1982). Environmental oxidation rate of manganese(II): bacterial catalysis. Geochim. Cosmochim. Acta 46, 1073-1079.

Emerson, S. R., and Huested, S. S. (1991). Ocean anoxia and the concentration of molybdenum and vanadium in seawater. Mar. Chem. 34, 177-196.

Falkowski, P. G. (1997). Evolution of the nitrogen cycle and its influence on the biological sequestration of $\mathrm{CO}_{2}$ in the ocean. Nature 387, 272-275.

Fan, S. -M. (2008). Photochemical and biochemical controls on reactive oxygen and iron speciation in the pelagic surface ocean. Mar. Chem. 109, 152-164.

Field, C. B., Behrenfeld, M. J., Randerson, J. T., and Falkowski, P. (1998). Primary production of the biosphere: integrating terrestrial and oceanic components. Science 281, 237-240.

Finney, L. A., and O'Halloran, T. V. (2003).Transition metal speciation in the cell: insights from the chemistry of metal ion receptors. Science 300, 931-936.

Franck, V. M., Bruland, K. W., Hutchins, D. A., and Brzezinski, M. A. (2003). Iron and zinc effects on silicic acid and nitrate uptake kinetics in three high-nutrient, low-chlorophyll (HNLC) regions. Mar. Ecol. Prog. Ser. 252, 15-33.

Gledhill, M., and Buck, K. N. (2012). The organic complexation of iron in the marine environment: a review. Front. Microbiol. 3:69. doi:10.3389/fmicb.2012.00069

Gledhill, M., and van den Berg, C. M. G. (1994). Determination of complexation of iron(III) with natural organic complexing ligands in seawater using cathodic stripping voltammetry. Mar. Chem. 47, 41-54.

Granéli, E., and Risinger, L. (1994). Effects of cobalt and vitamin B12 on the growth of Crysochromulina polylepis (Prymnesiophyceae). Mar. Ecol. Prog. Ser. 113, 177-183.

Guo, J., Annett, A. L., Taylor, R. L., Lapi, S., Ruth, T. J., and Maldonado, M. T. (2010). Copper-uptake kinetics of coastal and oceanic diatoms. $J$. Phycol. 46, 1218-1228.

Guo, J., Lapi, S., Ruth, T. J., and Maldonado, M. T. (2012). The effects of iron and copper availability on the copper stoichiometry of marine phytoplankton. J. Phycol. 48, 312-325.

Hartwig, A. (2001). Zinc finger proteins as potential targets for toxic metal ions: differential effects on structure and function. Antioxid. Redox Signal. 3, 625-634. 
Hassler, C. S., Alasonati, E., Mancuso Nichols, C. A., and Slaveykova, V. I. (2011a). Exopolysaccharides produced by bacteria isolated from the pelagic Southern Ocean - role in Fe binding, chemical reactivity, and bioavailability. Mar. Chem. 123, 88-98.

Hassler, C. S., Schoemann, V., Nichols, C. M., Butler, E. C. V., and Boyd, P. W. (2011b). Saccharides enhance iron bioavailability to southern ocean phytoplankton. Proc. Natl. Acad. Sci. U.S.A. 108, 1076-1081.

Ho, T. -Y., Quigg, A., Finkel, Z. V., Milligan, A. J., Wyman, K., Falkowski, P. G., and Morel, F. M. M. (2003). The elemental composition of some marine phytoplankton. J. Phycol. 39, 1145-1159.

Hopkinson, B. M., and Barbeau, K. A. (2008). Interactive influences of iron and light limitation on phytoplankton at subsurface chlorophyll maxima in the eastern North Pacific. Limnol. Oceanogr. 53 1303-1318.

Hopkinson, B. M., and Barbeau, K. A. (2012). Iron transporters in marine prokaryotic genomes. Environ. Microbiol. 14, 114-128.

Hopkinson, B. M., and Morel, F. M. M. (2009). The role of siderophores in iron acquisition by photosynthetic marine microorganisms. Biometals 22, 659-669.

Hudson, R. J. M. ., and Morel, F. M. M. (1990). Iron transport in marine phytoplankton: kinetics of cellular and medium coordination reactions. Limnol. Oceanogr. 35, 1002-1020.

Hudson, R. J. M. (1998). Which aqueous species control the rates of trace metal uptake by aquatic biota? Observations and predictions of non-equilibrium effects. Sci. Total Environ. 219, 95-115.

Hudson, R. J. M., and Morel, F. M. M. (1993). Trace metal transport by marine microorganisms: implications of metal coordination kinetics. Deep Sea Res. 40, 129-150.

Hunter, K. A., and Boyd, P. W. (2007). Iron-binding ligands and their role in the ocean biogeochemistry of iron. Environ. Chem. 4, 221-232.

Hutchins, D. A., and Bruland, K. W. (1994). Grazer-mediated regeneration and assimilation of $\mathrm{Fe}, \mathrm{Zn}$, and Mn from planktonic prey. Mar. Ecol. Prog. Ser. 110, 259-269.

Hutchins, D. A., DiTullio, G. R., and Bruland, K. W. (1993). Iron and regenerated production: evidence for biological iron recycling in two marine environments. Limnol. Oceanogr. 38, 1242-1255.
Hutchins, D. A., Hare, C. E., Weaver, R. S., Zhang, Y., Firme, G. F., DiTullio, G. R., Alm, M. B., Riseman, S. F., Maucher, J. M., Geesey, M. E., Trick, C. G., Smith, G. J., Rue, E. L., Conn J., and Bruland, K. W. (2002). Phytoplankton iron limitation in the Humboldt current and Peru upwelling. Limnol. Oceanogr. 47, 997-1011.

Hutchins, D. A., Witter, A. E., Butler, A., and Luther, G. W. (1999). Competition among marine phytoplankton for different chelated iron speciation. Nature 400, 858-861.

Ito, Y., and Butler, A. (2005). Structure of synechobactins, new siderophores of the marine cyanobacterium Synechococcus sp. PCC 7002. Limnol. Oceanogr. 50, 1918-1923.

Jakuba, R. W., Moffett, J. W., and Dyhrman S. T. (2008), Evidence for the linked biogeochemical cycling of zinc, cobalt, and phosphorus in the western North Atlantic Ocean. Global Biogeochem. Cycles 22, GB4012.

Jickells, T. D., An, Z. S., Andersen, K. K., Baker, A. R., Bergametti, G., Brooks, N., Cao, J. J., Boyd, P. W., Duce, R. A., Hunter, K. A., Kawahata, H., Kubilay, N., LaRoche, J., Liss, P. S., Mahowald, N., Prospero, J. M., Ridgwell, A. J., Tegen, I., and Torres, R. (2005). Global iron connections between desert dust, ocean biogeochemistry and climate. Science 308, 67-71.

Jickells, T. D., and Burton, J. D. (1988). Cobalt, copper, manganese and nickel in the Sargasso Sea. Mar. Chem. 23, 131-144.

Jickells, T. D., and Spokes, L. J. (2001). "Atmospheric iron input to the oceans," in The Biogeochemistry of Iron in Seawater, eds D. R. Turner and K. A. Hunter (New York: Wiley), 85-121.

Johnson, K. S., Gordon, R. M., and Coale, K. H. (1997). What controls dissolved iron concentrations in the world ocean? Mar. Chem. 57, 137-161.

Jones, G. J., Palenik, B. P., and Morel, F. M. M. (1987). Trace metal reduction by phytoplankton: the role of plasmalemma redox enzymes. J. Phycol. 23, 237-244.

Katz, M. E., Fennel, K., and Falkowski, P. G. (2007). "Geochemical and biological consequences of phytoplankton evolution," in Evolution of Primary Production in the Sea, eds P. G. Falkowski and A. H. Knoll (Amsterdam: Elsevier), 405-430.

Kranzler, C., Lis, H., Shaked, Y., and Keren, N. (2011). The role of reduction in iron uptake processes in a unicellular, planktonic cyanobacterium. Environ. Microbiol. 13, 2990-2999.

Kuma, K., Nakabayashi, S., Suzuki, Y., Kudo, I., and Matsunaga, K. (1992). Photoreduction of Fe(III) by dissolved organic substances and existence of $\mathrm{Fe}(\mathrm{II})$ in seawater during spring blooms. Mar. Chem. 37, 15-27.

Kuma, K., Nishioka, J., and Matsunaga, K. (1996). Controls on iron(III) hydroxide solubility in seawater: the influence of $\mathrm{pH}$ and natural organic chelators. Limnol. Oceanogr. 41, 396-407.

Kustka, A. B., Allen, A. E., and Morel, F. M. M. (2007). Sequence analysis and transcriptional regulation of iron acquisition genes in two marine diatoms. J. Phycol. 43, 715-729.

Kustka, A. B., Sañudo-Wilhelmy, S., Carpenter, E. J., Capone, D., Burns, J., and Sunda, W. G. (2003a). Iron requirements for dinitrogen and ammonium supported growth in cultures of Trichodesmium (IMS 101): comparison with nitrogen fixation rates and iron:carbon ratios of field populations. Limnol. Oceanogr. 48, 1869-1884.

Kustka, A. B., Sanudo-Wilhelmy, S., Carpenter, E. J., Capone, D. G., and Raven, J. A. (2003b). A revised estimate of the iron use efficiency of nitrogen fixation, with special reference to the marine cynaobacterium trichodesmium spp. (Cyanophyta). J. Phycol. 39, 12-25.

Kustka, A. B., Shaked, Y., Milligan, A. J., King, D. W., and Morel, F. M. M. (2005). Extracellular production of superoxide by marine diatoms: contrasting effects on iron redox chemistry and bioavailabilty. Limnol. Oceanogr. 50, 1172-1180.

La Roche, J., Boyd, P. W., McKay, M. L., and Geider, R. J. (1996). Flavodoxin as an in situ marker for iron stress in phytoplankton. Nature 382 , 802-805.

Laglera, L. M., and van den Berg, C. M. G. (2009). Evidence for geochemical control of iron by humic substances in seawater. Limnol. Oceanogr. 54, 610-619.

Laglera, L. M., Battaglia, G., and van den Berg, C. M. G. (2011). Effect of humic substances on the iron speciation in natural waters by CLE/CSV. Mar. Chem. 127, 134-143.

Landing, W. M., and Bruland, K. W. (1987). The contrasting biogeochemistry of iron and manganese in the Pacific Ocean. Geochim. Cosmochim. Acta 51, 29-43.
Lane, E. S., Jang, K., Cullen, J. T., and Maldonado, M. T. (2008). The interaction between inorganic iron and cadmium uptake in the marine diatom Thalassiosira oceanica. Limnol. Oceanogr. 53, 1784-1789.

Lane, E. S., Semeniuk, D. M., Strzepek, R. F., Cullen, J. T., and Maldonado, M. T. (2009). Effects of iron limitation on intracellular cadmium of cultured phytoplankton: implications for surface dissolved cadmium to phosphate ratios. Mar. Chem. 115, 155-162.

Lane, T. W., and Morel, F. M. M. (2000). Regulation of carbonic anhydrase expression by zinc, cobalt, and carbon dioxidein the marine diatom Thalassiosira weissflogii. Plant Physiol. 123, 345-352.

Leal, M. F. C., and van den Berg, C. M. G. (1998). Evidence for strong copper(I) complexation by organic matter in seawater. Aquat. Geochem. 4, 49-75.

Lohan, M. C.,Crawford, D. W.,Purdie, D. A., and Statham, P. J. (2005). Iron and zinc enrichments in the northeastern subarctic Pacific: ligand production and zinc availability in response to phytoplankton growth. Limnol. Oceanogr. 50, 1427-1437.

Lomas, M. W., Burke, A. L., Lomas, D. A., Bell, D. W., Shen, C., Dyhrman, S. T., and Ammerman, J. W. (2010) Sargasso Sea phosphorus biogeochemistry: an important role for dissolved organic phosphorus (DOP). Biogeosciences 7, 695-710.

Lui, X., and Millero, F. J. (2002). The solubility of iron in seawater. Mar. Chem. 77, 43-54.

Macrellis, H. M., Trick, C. G., Rue, E. L., Smith, G., and Bruland, K. W. (2001). Collection and detection of natural iron-binding ligands from seawater. Mar. Chem. 76, 175-187.

Maldonado, M. T., Allen, A. E., Chong, J. S., Lin, K., Leus, D., Karpenko, N., and Harris, S. L. (2006). Copper-dependent iron transport in coastal and oceanic diatoms. Limnol. Oceanogr. 51, 1729-1743.

Maldonado, M. T., Boyd, P. W., Harrison, P. J., and Price, N. M. (1999). Co-limitation of phytoplankton growth by light and Fe during winter in the NE subarctic Pacific Ocean. Deep Sea Res. 46, 2475-2485.

Maldonado, M. T., and Price, N. M. (1996). Influence of N substrate on Fe requirements of marine centric diatoms. Mar. Ecol. Prog. Ser. 141, 161-172.

Maldonado, M. T., and Price, N. M. (2001). Reduction and transport of organically bound iron by 
Thalassiosira oceanica. J. Phycol. 37, 298-310.

Maldonado, M. T., Strzepek, R. F., Sander, S., and Boyd, P. W. (2005). Aquisition of iron bound to strong organic complexes, with different Fe binding groups and photochemical reactivities, by plankton communities in Fe-limited subantarctic waters. Global Biogeochem. Cycles 19, GB4S23.

Marchetti, A., Maldonado, M. T., Lane, E. S., and Harrison, P. J. (2006). Iron requirements of the pennate diatom Pseudo-nitzschia: comparison of oceanic (high-nitrate, low-chlorophyll waters) and coastal species. Limnol. Oceanogr. 51, 2092-2101.

Marchetti, A., Parker, M. S., Moccia, L. P., Lin, E. O., Arrieta, A. L, Ribalet, F., Murphy, M. E. P., Maldonado, M. T., and Armbrust, E. V. (2009). Ferritin is used for iron storage in bloomforming marine pennate diatoms. Nature 457, 467-470.

Martin, J. H. (1990). Glacial-interglacial $\mathrm{CO} 2$ change: the iron hypothesis. Paleoceanography 5, 1-13.

Martin, J. H., Bruland, K. W., and Broenkow, W. W. (1976). "Cadmium transport in the California current," in Marine Pollutant Transfer, eds H. L. Windom and R. A. Duce (Toronto: D. C Health and Co.), 159-184.

Martin, J. H., and Fitzwater, S. E. (1988). Iron deficiency limits phytoplankton growth in the north-east Pacific subarctic. Nature 331, 341-343.

Martin, J. H., Fitzwater, S. E, Gordon R. M., Hunter, C. N., and Tanner, S. J. (1993). Iron, primary production and carbon-nitrogen flux studies during the JGOFS North Atlantic Bloom Experiment. Deep Sea Res. 40, 115-134.

Martin, J. H., Gordon, R. M., Fitzwater, S., and Broenkow, W. W. (1989). VERTEX: phytoplankton/iron studies in the Gulf of Alaska. Deep Sea Res. 36, 649-680.

Martin, J. H., Gordon, R. M., and Fitzwater, S. E. (1990). Iron in Antarctic waters. Nature 345, 156-158.

Martin, J. H., Gordon, R. M., and Fitzwater, S. E. (1991). The case for iron. Limnol. Oceanogr. 36, 1793-1802.

Martinez, J. S., Zhang, G. P., Holt, P. D., Jung, H. -T., Carrano, C. J., Haygood, M. G., and Butler, A. (2000). Self-assembling amphiphilic siderophores from marine bacteria. Science 287, 1245-1247.

Martínez-Garcia, A., Rosell-Mele, A., Jaccard, S. L., Geibert, W., Sigman,
D. M., and Haug, G. H. (2011). Southern Ocean dust-climate coupling over the past four million years. Nature 476, 312-315.

Mauzerall, D. (2007). "Oceanic photochemistry and evolution of elements and cofactors in the early stages of the evolution of life," in Evolution of Primary Production in the Sea, eds P. G. Falkowski and A. H. Knoll (Amsterdam: Elsevier), 7-19.

Mawji, E., Gledhill, M., Milton, J. A., Tarran, G. A., Ussher, S., Thompson, A., Wolff, G. A., Worsfold, P. J., and Achterberg, E. P. (2008). Hydroxamate siderophores: occurrence and importance in the Atlantic Ocean. Environ. Sci. Technol. 42, 8675-8680.

Mawji, E., Gledhill, M., Milton, J. A., Zubkov, M. V., Thompson, A., Wolff, G. A., and Achterberg, E. P. (2011). Production of siderophore type chelates in Atlantic Ocean waters enriched with different carbon and nitrogen sources. Mar. Chem. 124, 90-99.

Measures, C. I., and Vink, S. (1999). Seasonal variations in the distribution of $\mathrm{Fe}$ and $\mathrm{Al}$ in the surface waters of the Arabian Sea. Deep Sea Res. 46, 1597-1622.

Moffett, J. W. (1990). Microbially mediated cerium oxidation in sea water. Nature 345, 421-423.

Moffett, J. W. (1995). Temporal and spatial variability of strong copper complexing ligands in the Sargasso Sea. Deep Sea Res. 42, 1273-1295.

Moffett, J. W., and Brand, L. E. (1996). Production of strong, extracellular $\mathrm{Cu}$ chelators by marine cyanobacteria in response to $\mathrm{Cu}$ stress. Limnol. Oceanogr. 41, 388-395.

Moffett, J. W., and Dupont, C. (2007). $\mathrm{Cu}$ complexation by organic ligands in the sub-arctic NW Pacific and Bering Sea. Deep Sea Res. 154, 586-595.

Moffett, J. W., and Ho, J. (1996). Oxidation of cobalt and manganese in seawater via a common microbially catalyzed pathway. Geochim. Cosmochim. Acta 60, 3415-3424.

Moffett, J. W., and Zika, R. G. (1988). Measurement of copper(I) in surface waters of the subtropical Atlantic and Gulf of Mexico. Geochim. Cosmochim. Acta 52, 1849-1857.

Montoya, J. P., Holl, C. M., Zehr, J. P., Hansen, A., Villareal, T. A., and Capone, D. G. (2004). High rates of $\mathrm{N}_{2}$ fixation by unicellular diazotrophs in the oligotrophic Pacific Ocean. Nature 430, 1027-1031.

Moore, J., Doney, S., and Lindsay, K. (2004). Upper ocean ecosystem dynamics and iron cycling in a global three-dimensional model. Global Biogeochem. Cycles 18, ARTN GB4028, doi: 10.1029/2004GB002220

Moore, J. K., and Braucher, O. (2008). Sedimentary and mineral dust sources of dissolved iron to the world ocean. Biogeoscience 5, 631-656.

Moore, J. K., Doney, S. C., Glover, D. M., and Fung, I. Y. (2002). Iron cycling and nutrient-limitation patterns in surface waters of the World Ocean. Deep Sea Res. II 49, 463-507.

Morel, F. M. M., Kustka, A. B., and Shaked, Y. (2008). The role of unchelated $\mathrm{Fe}$ in the iron nutrition of phytoplankton. Limnol. Oceanogr. $53,400-404$.

Morel, F. M. M., Reinfelder, J. R. Roberts, S. B., Chamberlain, C. P., Lee, J. G., and Yee, D. (1994). Zinc and carbon co-limitation of marine phytoplankton. Nature 369 740-742.

Morford, J., and Emerson, S. (1999). Geochemistry of redox sensitive trace metals in sediments. Geochim. Cosmochim. Acta 63, 1735-1750.

Morgan, J. J. (1967). "Chemical equilibria and kinetic properties of manganese in natural waters" in Principles and Applications of Water Chemistry, eds S. D. Faust and J. V. Hunter (New York, Wiley), 561-620.

Ozturk, M., Croot, P. L., Bertilsson, S., Abrahamssond, K., Karlsone, B., Davidf, R., Franssong, A., and Sakshaug, E. (2004). Iron enrichment and photoreduction of iron under UVand PAR in the presence of hydroxycarboxylic acid: implications for phytoplankton growth in the Southern Ocean. Deep Sea Res. II 51, 2841-2856.

Panzeca, C., Beck, A. J., Leblanc, K., Taylor, G. T., Hutchins, D. A. and Sañudo-Wilhelmy, S. A. (2008). Potential cobalt limitation of vitamin B12 synthesis in the North Atlantic Ocean. Global Biogeochem. Cycles 22, GB2029.

Park, H., Song, B., and Morel, F. M. M. (2007). Diversity of the cadmiumcontaining carbonic anhydrase in marine diatoms and natural waters. Environ. Microbiol. 9, 403-413.

Peers, G., and Price, N. M. (2004) A role for manganese in superoxide dismutases and growth of irondeficient diatoms. Limnol. Oceanogr. 49, 1774-1783.

Peers, G., and Price, N. M. (2006) Copper-containing plastocyanin used for electron transport by an oceanic diatom. Nature 441, 341-344.

Peers, G., Quesnel, S. A., and Price, N. M. (2005). Copper requirements for iron acquisition and growth of coastal and oceanic diatoms. Limnol. Oceanogr. 50, 1149-1158.

Poorvin, L., Rinta-Kanto, J. M., Hutchins, D. A., and Wilhelm, S. W. (2004). Viral release of iron and its bioavailability to marine plankton. Limnol. Oceanogr. 49, 1734-1741.

Price, N. M., Ahner, B. A., and Morel, F. M. M. (1994). The equatorial Pacific Ocean: grazercontrolled phytoplancton population in an iron-limited ecosystem. Limnol. Oceanogr. 39, 520-534.

Price, N. M., Andersen, L. F., and Morel, F. M. M. (1991). Iron and nitrogen nutrition of equitorial Pacific plankton. Deep Sea Res. 38, 1361-1378.

Price, N. M., and Morel, F. M. M. (1990). Cadmium and cobalt substitution for zinc in a marine diatom. Nature 344, 658-660.

Price, N. M., and Morel, F. M. M. (1991). Colimitation of phytoplankton growth by nickel and nitrogen. Limnol. Oceanogr. 36, 1071-1077.

Raven, J. A. (1988). The iron and molybdenum use efficiences of plant growth with different energy, carbon and nitrogen sources. New Phytol. 109, 279-287.

Raven, J. A. (1990). Predictions of $\mathrm{Mn}$ and $\mathrm{Fe}$ use efficiencies of phototrophic growth as a function of light availability for growth and $\mathrm{C}$ assimilation pathway. New Phytol. 116, 1-18.

Raven, J. A., Evans, M. C. W., and Korb, R. E. (1999). The role of trace metals in photosynthetic electron transport in O2-evolving organisms. Photosyn. Res. 60, 111-149.

Redfield, A. C., Ketchum, B. H., and Richards, F. A. (1963). "The influence of organisms on the composition of sea-water," in The Sea, ed. M. N. Hill (New York: Interscience Publication), 26-77.

Rose, A. L., Salmon, T. P., Lukondeh, T., Neilan, B. A., and Waite, T. D. (2005). Use of superoxide as an electron shuttle for iron acquisition by the marine cyanobacterium Lyngbya majuscula. Environ. Sci. Technol. 39, 3708-3715.

Roy, E. G., and Wells, M. L. (2011). Evidence for regulation of $\mathrm{Fe}(\mathrm{II})$ oxidation by organic complexing ligands in the Eastern Subarctic Pacific. Mar. Chem. 127, 115-122.

Roy, E. G., Wells, M. L., and King, D. W. (2008). Persistence of iron(II) in surface waters of the western subarctic Pacific. Limnol. Oceanogr. 53, 89-98.

Rubin, M., Berman-Frank, I., and Shaked, Y. (2011). Dust- and mineral-iron utilization by the 
marine dinitrogen-fixer Trichodesmium. Nat. Geosci. 4, 529-534.

Rue, E., and Bruland, K. (2001). Domoic acid binds iron and copper: a possible role for the toxin produced by the marine diatom Pseudo-nitzschia. Mar. Chem. 76, 127-134.

Rue, E. L., and Bruland, K. W. (1995). Complexation of iron(III) by natural organic-ligands in the central north pacific as determined by a new competitive ligand equilibration adsorptive cathodic stripping voltammetric method. Mar. Chem. 50, 117-138.

Rueter, J. G. (1983). Theoretical iron limitation of microbial $\mathrm{N}_{2}$ fixation in the oceans. Eos (Washington DC) 63,445 .

Rueter, J. G., Hutchins, D. A., Smith, R. W., and Unsworth, N. L. (1992). "Iron nutrition of Trichodesmium," in Marine pelagic cyanobacteria: Trichodesmium and other Diazotrophs, eds E. J. Carpenter, D. G. Capone, and J. G. Rueter (Dordrecht: Kluwer), 289-306.

Saito, M. A., Bertrand, E. M., Bulygin, V., Moran, D., Dutkiewicz, S. Monteiro, F. M., Follows, M. J., Valois, F. W., and Waterbury, J. B. (2011). Iron conservation by reduction of metalloenzyme inventories in the marine diazotroph Crocosphaera watsonii. Proc. Natl. Acad. Sci. U.S.A. 108, 2184-2189.

Saito, M. A., and Goepfert, T. J. (2008). Zinc-cobalt colimitation of Phaeocystis antarctica. Limnol. Oceanogr. 53, 266-275.

Saito, M. A., and Moffett, J. W. (2001). Complexation of cobalt by natural organic ligands in the Sargasso Sea as determined by a new high-sensitivity electrochemical cobalt speciation method suitable for open ocean work. Mar. Chem. 75, 49-68.

Saito, M. A., Moffett, J. W., Chisholm, S. W., and Waterbury J. B. (2002). Cobalt limitation and uptake in Prochlorococcus. Limnol. Oceanogr. 47, 1629-1636.

Saito, M. A., Moffett, J. W., and DiTullio, G. R. (2004). Cobalt and nickel in the Peru upwelling region: a major flux of labile cobalt utilized as a micronutrient. Global Biogeochem. Cycles 18, GB4030, doi: $10.1029 / 2003$ GB002216

Saito, M. A., Rocap, G., and Moffett, J. W. (2005). Production of cobalt binding ligands in a Synechococcus feature at the Costa Rica upwelling dome. Limnol. Oceanogr. 50, 279-290.

Saito, M. A., Sigman, D. M., and Morel, F. M. M. (2003). The bioinorganic chemistry of the ancient ocean: the co-evolution of cyanobacterial metal requirements and biogeochemical cycles at the Archean-Proterozoci boundary? Inorgan. Chem. Acta 356, 308-318.

Sandy, M., and Butler, A. (2009). Microbial iron acquisition: marine and terrestrial siderophores. Chem. Rev. 109, 4580-4595.

Santana-Casiano, J. M., GonzaalezDavila, M., and Millero, F. J. (2005). Oxidation of nanomolar levels of $\mathrm{Fe}(\mathrm{II})$ with oxygen in natural waters. Environ. Sci. Technol. 39, 2073-2079.

Sarthou, G., Bucciarelli, E., Chever, F., Hansard, S. P., Gonzalez-Davila, M., Santana-Casiano, J. M., Planchon, F., and Speich, S. (2011). Labile Fe(II) concentrations in the Atlantic sector of the Southern Ocean along a transect from the subtropical domain to the Weddell Sea Gyre. Biogeosciences 8, 2461-2479.

Scanlan, D. J., Ostrowski, M., Mazard, S., Dufresne, A., Garczarek, L., Hess, W. R., Post, A. F., Hagemann, M., Paulsen, I., and Partensky, F. (2009). Ecological genomics of marine picocyanobacteria. Microb. Mol. Biol. Rev. 73, 249-299.

Schindler, D. W. (1977). Evolution of phosphorus limitation in lakes. Science 195, 260-262.

Shaked, Y. (2008). Iron redox dynamics in the surface waters of the Gulf of Aqaba, Red Sea. Geochim. Cosmochim. Acta 72, 1540-1554.

Shaked, Y., Kustka, A. B., and Morel, F. M. M. (2005). A general kinetic model for iron aquisition by eucaryotic phytoplankton. Limnol. Oceanogr. 50, 872-882.

Shaked, Y., and Lis, H. (2012). Disassembling iron availability to phytoplankton. Front. Microbiol. Chem. 3:123. doi:10.3389/fmicb.2012.00123

Shaked, Y., Xu, Y., Leblanc, K., and Morel, F. M. M. (2006). Zinc availability and alkaline phosphatase activity in Emiliania huxleyi: implications for $\mathrm{Zn}-\mathrm{P}$ co-limitation in the ocean. Limnol. Oceanogr. 51, 299-309.

Sharma, V. K., and Millero, F. J. (1988). Oxidation of copper(I) in seawater. Environ. Sci. Technol. 22, 768-771.

Sigman, D. M., and Boyle, E. A. (2000). Glacial/interglacial variations in atmospheric carbon dioxide. Nature 407, 859-869.

Sohm, J. A., Webb, E. A., and Capone, D. G. (2011). Emerging patterns of marine nitrogen fixation. Nat. Rev. Microbiol. 9, 499-508.

Steigenberger, S., Statham, P. J., Voelker, C., and Passow, U. (2010). The role of polysaccharides and diatom exudates in the redox cycling of $\mathrm{Fe}$ and the photoproduction of hydrogen peroxide in coastal seawaters. Biogeosciences 7, 109-119.

Strzepek, R. F., and Harrison, P. J. (2004). Photosynthetic architecture differs in coastal and oceanic diatoms. Nature 431, 689-692.

Strzepek, R. F., Maldonado, M. T., Higgins, J. L., Hall, J., Safi, K., Wilhelm, S. W., and Boyd, P. W. (2005). Spinning the "Ferrous Wheel": the importance of the microbial community in an iron budget during the $\mathrm{FeCy}$ cle experiment. Global Biogeochem. Cycles 19, GB4S26.

Strzepek, R. F., Maldonado, M. T., Hunter, K. A., Frew, R. D., and Boyd, P. W. (2011). Adaptive strategies by Southern Ocean phytoplankton to lessen iron limitation: uptake of organically complexed iron and reduced cellular iron requirements. Limnol. Oceanogr. 56, 1983-2002.

Sunda, W., and Huntsman, S. (2003). Effect of $\mathrm{pH}$, light, and temperature on Fe-EDTA chelation and Fe hydrolysis in seawater. Mar. Chem. 84, 35-47.

Sunda, W. G. (2001). "Bioavailability and bioaccumulation of iron in the sea," in The Biogeochemistry of Iron in Seawater, eds D. R. Turner and K. A. Hunter (New York: Wiley), 41-84. Sunda, W. G., and Huntsman, S. A. (1985). Regulation of cellular manganese and manganese transport rates in the unicellular alga Chlamydomonas. Limnol. Oceanogr. 30, 71-80.

Sunda, W. G., and Huntsman, S. A. (1986). Relationships among growth rate, cellular manganese concentrations and manganese transport kinetics in estuarine and oceanic species of the diatom Thalassiosira. J. Phycol. 22, 259-270.

Sunda, W. G., and Huntsman, S. A. (1988). Effect of sunlight on redox cycles of manganese in the southwestern Sargasso Sea. Deep Sea Res. 35, 1297-1317.

Sunda, W. G., and Huntsman, S. A. (1992). Feedback interactions between zinc and phytoplankton in seawater. Limnol. Oceanogr. 37, 25-40.

Sunda, W. G., and Huntsman, S. A. (1994). Photoreduction of manganese oxides in seawater. Mar. Chem. 46, 133-152.

Sunda, W. G., and Huntsman, S. A. (1995a). Cobalt and zinc interreplacement in marine phytoplankton: biological and geochemical implications. Limnol. Oceanogr. 40, 1404-1417.

Sunda, W. G., and Huntsman, S. A. (1995b). Iron uptake and growth limitation in oceanic and coastal phytoplankton. Mar. Chem. 50, 189-206.

Sunda, W. G., and Huntsman, S. A. (1995c). Regulation of copper concentration in the oceanic nutricline by phytoplankton uptake and regeneration cycles. Limnol. Oceanogr. 40, 132-137.

Sunda, W. G., and Huntsman, S. A. (1996). Antagonisms between cadmium and zinc toxicity and manganese limitation in a coastal diatom. Limnol. Oceanogr. 41, 373-387.

Sunda, W. G., and Huntsman, S. A. (1997). Interrelated influence of iron, light and cell size on marine phytoplankton growth. Nature 390, 389-392.

Sunda, W. G., and Huntsman, S. A. (1998a). Control of Cd concentrations in a coastal diatom by interactions among free ionic $\mathrm{Cd}, \mathrm{Zn}$, and $\mathrm{Mn}$ in seawater. Environ. Sci. Technol. 32, 2961-2968.

Sunda, W. G., and Huntsman, S. A. (1998b). Processes regulating cellular metal accumulation and phsiological effects: phytoplankton as model systems. Sci. Total Environ. 219, 165-181.

Sunda, W. G., and Huntsman, S. A. (1998c). Interactions among $\mathrm{Cu}^{2+}$ $\mathrm{Zn}^{2+}$, and $\mathrm{Mn}^{2+}$ in controlling cellular $\mathrm{Mn}, \mathrm{Zn}$, and growth rate in the coastal alga Chlamydomonas. Limnol. Oceanogr. 43, 1055-1064.

Sunda, W. G., and Huntsman, S. A. (1998d). Interactive effects of external manganese, the toxic metals copper and zinc, and light in controlling cellular manganese and growth in a coastal diatom. Limnol. Oceanogr. 43, 1467-1475.

Sunda, W. G., and Huntsman, S. A. (2000). Effect of $\mathrm{Zn}, \mathrm{Mn}$, and $\mathrm{Fe}$ on $\mathrm{Cd}$ accumulation in phytoplankton: implications for oceanic Cd cycling. Limnol. Oceanogr. 45, 1501-1516.

Sunda, W. G., and Huntsman, S. A. (2004). Relationships among photoperiod, carbon fixation, growth, chlorophyll a and cellular iron and zinc in a coastal diatom. Limnol. Oceanogr. 49, 1742-1753.

Sunda, W. G., and Huntsman, S. A. (2005). Effect of CO2 supply and demand on zinc uptake and growth limitation in a coastal diatom. Limnol. Oceanogr. 50, 1181-1192.

Sunda, W. G., and Huntsman, S. A. (2011). Interactive effects of light and temperature on iron limitation in a marine diatom: implications for marine productivity and carbon cycling. Limnol. Oceanogr. 56 , 1475-1488. 
Sunda, W. G. (1988/1989). Trace metal interactions with marine phytoplankton. Biol. Oceanogr. 6, 411-442.

Tebo, B., Nealson, K., Emerson, S., and Jacobs, L. (1984). Microbial meditation of $\mathrm{Mn}(\mathrm{II})$ and $\mathrm{Co}(\mathrm{II})$ precipitation at the $\mathrm{O}_{2} / \mathrm{H}_{2}$ interfaces in two anoxic fjords. Limnol. Oceanogr. 29, 1247-1258.

Tebo, B. M., Bargar, J. R., Clement, B. G., Dick, G. J., Murray, K. J., Parker D., Verity, R., and Webb, S. M. (2004). Biogenic manganese oxides: properties and mechanisms of formation. Annu. Rev. Earth Planet. Sci. 32, 287-328.

Tovar-Sanchez, A., Sanudo-Wilhelmy, S. A., Garcia-Vargas, M., Weaver, R. S., Popels, L. C., and Hutchins, D. A. (2003). A trace metal clean reagent to remove surface bound iron from marine phytoplankton. Mar. Chem. 82, 91-99.

Trouwborst, R. E., Clement, B. G., Tebo, B. M., Glazer, B, T., and Luther, G. W. (2006). Soluble $\mathrm{Mn}(\mathrm{III})$ in suboxic zones. Science 313, 1955-1957.

Twining, B. S., Baines, S. B., Bozard, J. B., Vogt, S., Walker E. A., and Nelson, D. M. (2011). Metal quotas of plankton in the equatorial Pacific Ocean. Deep Sea Res. II Top. Stud. Oceanogr. 58, 325-341.

Twining, B. S., Baines, S. B., and Fisher, N. S. (2004). Element stoichiometries of individual plankton cells collected during the southern ocean iron experiment (SOFeX). Limnol. Oceanogr. 49, 2115-2128.
Twining, B. S., Nunez-Milland, D.,Vogt, S., Johnson, R. S., and Sedwick, P. N. (2010). Variations in Synechococcus cell quotas of phosphorus, sulfur, manganese, iron, nickel, and zinc within mesoscale eddies in the Sargasso Sea. Limnol. Oceanogr. 55, 492-506.

Valko, M., Morris, H., and Cronin, M. T. D. (2005). Metals, toxicity and oxidative stress. Curr. Med. Chem. 12, 1161-1208.

Velasquez, I., Nunn, B. L., Ibisanmi, E. Goodlet, D. R., Hunter, K. A., and Sander,S. G. (2011). Detection of hydroxamate siderophores in coastal and sub-antarctic waters off the southeastern coast of New Zealand. Mar. Chem. 126, 97-107.

Voelker, B. M., and Sedlak, D. L. (1995). Iron reduction by photoproduced superoxide in seawater. Mar. Chem. 50, 93-102.

Vong, L., Laes, A., and Blain, S. (2007). Determination of iron-porphyrinlike complexes at nanomolar levels in seawater. Anal. Chim. Acta 588, 237-244.

Vraspir, J. M., and Butler, A. (2009). Chemistry of marine ligands and siderophores. Annu. Rev. Mar. Sci. 1, 43-63.

Waite, T. D., Szymczak, R., Espey, Q. I., and Furnas, M. J. (1995). Diel variations in iron speciation in northern Australian shelf waters. Mar. Chem. 50, 79-92.

Walsby, A. E. (1992). “The gas vesicles and buoyancy of Trichodesmium," in Marine Pelagic Cyanobacteria: Trichodesmium and Other Diazotrophs, eds E. J. Carpenter, D. G. Capone, and J. G. Rueter (Dordrecht: Kluwer), 141-161.

Wells, M. L., Mayer, L. M., and Guillard, R. R. L. (1991). A chemical method for estimating the availability of iron to phytoplankton in seawater. Mar. Chem. 33, 23-40.

Wilhelm, S. W., and Trick, C. G. (1994). Iron-limited growth of cyanobacteria: multiple siderophore production is a common response. Limnol. Oceanogr. 39, 1979-1984.

Wolfe-Simon, F., Starovoytov, V., Reinfelder, J. R., Schofield, O., and Falkowski, P. J. (2006). Localization and role of manganese superoxide dismutase in a marine diatom. Plant Physiol. 142, 1701-1709.

Wu, J., Boyle E., Sunda W., and Wen, L. -S. (2001). Soluble and colloidal iron in the oligotrophic North Atlantic and North Pacific. Science 293, 847-849.

Wu, J., Sunda, W. G., Boyle, E. A., and Karl, D. M. (2000). Phosphate depletion in the western North Atlantic Ocean. Science 289, 759-762.

Xu., Y., Feng, L., Jeffrey, P. D., Shi Y. and Morel, F. M. M. (2008). Structure and metal exchange in the cadmium carbonic anhydrase of marine diatoms. Nature 452, 56-61.

Xu., Y., Tang, D., Shaked, Y., and Morel, F. M. M. (2007). Zinc, cadmium, and cobalt interreplacement and relative use efficiencies in the coccolithophore Emiliania huxleyi. Limnol. Oceanogr. 52, 2294-2305.

Yoshida, M., Kuma, K., Iwade, S., Isoda Y., Takata, H., and Yamada, M.
(2006). Effect of aging time on the availability of freshly precipitated ferric hydroxide to coastal marine diatoms. Mar. Biol. 149, 379-392.

Zehr, J. P. (2011). Nitrogen fixation by marine cyanobacteria. Trends Microbiol. 19, 162-173.

Zehr, J. P., Waterbury, J. B., Turner, P. J., Montoya, J. P., Omoregie, E., Steward, G. F., Hansen, A., and Karl, D. M. (2001). Unicellular cyanobacteria fix N2 in the subtropical North Pacific Ocean. Nature 412, 6 35-638.

Conflict of Interest Statement: The author declares that the research was conducted in the absence of any commercial or financial relationships that could be construed as a potential conflict of interest.

Received: 28 December 2011; accepted: 17 May 2012; published online: 07 June 2012.

Citation: Sunda WG (2012) Feedback interactions between trace metal nutrients and phytoplankton in the ocean. Front. Microbio. 3:204. doi: 10.3389/fmicb.2012.00204

This article was submitted to Frontiers in Microbiological Chemistry, a specialty of Frontiers in Microbiology.

Copyright (c) 2012 Sunda. This is an open-access article distributed under the terms of the Creative Commons Attribution Non Commercial License, which permits non-commercial use, distribution, and reproduction in other forums, provided the original authors and source are credited. 